\title{
Implications of Entrepreneurial Intentions of Romanian Secondary Education Students, over the Romanian Business Market Development
}

\author{
Amalia Furdui ${ }^{1}$ (D), Lucian Lupu-Dima ${ }^{2}$ and Eduard Edelhauser ${ }^{3, *}$ (D) \\ 1 Management and Industrial Engineering Department, University of Petrosani, 332006 Petroșani, Romania; \\ amaliafurdui@gmail.com \\ 2 Mining Engineering, Surveying and Construction Department, University of Petroșani, \\ 332006 Petroșani, Romania; lucianlupu@upet.ro \\ 3 Head of the Management and Industrial Engineering Department, University of Petrosani, \\ 332006 Petroșani, Romania \\ * Correspondence: eduardedelhauser@upet.ro; Tel.: +40-722562167
}

Citation: Furdui, A.; Lupu-Dima, L.; Edelhauser, E. Implications of Entrepreneurial Intentions of Romanian Secondary Education Students, over the Romanian Business Market Development. Processes 2021, 9, 665. https:// doi.org/10.3390/pr9040665

Academic Editor: Lucian-Ionel Cioca

Received: 22 March 2021

Accepted: 7 April 2021

Published: 9 April 2021

Publisher's Note: MDPI stays neutral with regard to jurisdictional claims in published maps and institutional affiliations.

Copyright: (c) 2021 by the authors. Licensee MDPI, Basel, Switzerland. This article is an open access article distributed under the terms and conditions of the Creative Commons Attribution (CC BY) license (https:// creativecommons.org/licenses/by/ $4.0 /)$.

\begin{abstract}
The study investigates the Romanian entrepreneurial education training program emphasizing the secondary education student entrepreneurial intents included in technical and professional Vocational Education Training (VET) programs, in order to identify its role in increasing student intention in the process of choosing a career as an entrepreneur among graduates of the vocational and technical Romanian education system. The study research methodology was based on the interpretation of two questionnaires consisting of 23 questions, which were applied to a population of 253 and 159 respondents. The survey period was conducted between 2019 and 2020. The respondents were students from the vocational and technical education system in Romania, mostly from the Central Region of Romania, but the results of the study could be extended to the entire Romanian education system. The data were processed using SPSS software, and the results of the study revealed direct, positive, and significant links between psychological and behavioral traits and entrepreneurial intentions of the student surveyed, moderated by the entrepreneurial education acquired through the school curriculum. These results could also be the basis for developing future policies and programs to encourage entrepreneurial behavior, especially for secondary education students from the Romanian education system, specifically on pre-university education.
\end{abstract}

Keywords: sustainable process; resource efficiency; entrepreneurship; entrepreneurial intentions; education for sustainable development; innovation

\section{Introduction}

Over the last decade, entrepreneurship has become an important economic and social topic, as well as a well-known research topic in the world. Entrepreneurship is important because it leads to increased economic efficiency, creates new jobs, and brings innovation to the market. The majority of empirical studies have shown that entrepreneurship can be learned, and education can stimulate young people's intention to become an entrepreneur. This has contributed to a continuous increase in the number of entrepreneurship programs; however, the impact that entrepreneurial education has on the intention to become an entrepreneur has remained largely unexplored. The study of youth entrepreneurship contributes to a better understanding of the process of creating employment opportunities for young people. Against the background of the need to stimulate youth employment, entrepreneurship is an important alternative for negotiating the transition from school to work. However, not many aspects of young people's entrepreneurial attitudes, young people's entrepreneurial motivations, and incentives and barriers are known $[1,2]$.

This study aims to investigate the role of entrepreneurial education programs in the entrepreneurial intention of young people, in order to identify the role that entrepreneur- 
ship education has on increasing young people's intention in the process of choosing an entrepreneur career among graduates of vocational and technical education in Romania, Centre Region. It is known that reducing youth unemployment is a key objective for policy-makers in developed or developing countries. Analysis of labor market indicators by age grouping shows the need to create jobs for young people. Youth unemployment represents a significant loss of human capital that could contribute to economic growth. Moreover, economies face the need to create employment opportunities for young people, and entrepreneurship is an important way of entering the labor market; and thus, entrepreneurship could contribute to better use of young people's economic potential in order to reduce poverty. Stimulating entrepreneurship among young people brings multiple economic and social benefits, such as reducing unemployment, promoting social inclusion, improving self-confidence among young people, reducing the risk of juvenile delinquency, and stimulating innovation. Thus, companies must support young people's entrepreneurship because it is a valuable source of new jobs and economic dynamism. However, it should be noted that researchers are cautious in treating young people's entrepreneurship as a solution to economic and social problems.

Entrepreneurship is the process in which individuals become aware that business development is a viable option for them by formulating business ideas, learning needed skills for an entrepreneur, and taking the necessary steps to start and develop a business [3,4]. On the other hand, entrepreneurship is seen in close connection with traits such as initiative, innovation, creativity, risk-taking, and the ability to perform in specific economic and cultural environments. Entrepreneurial behavior among young people is also sensitive to a multitude of factors, including entrepreneurship education, institutional and business environment, and access to financing mechanisms [5,6].

\section{Materials and Methods}

In this study, the authors conducted an analysis of the impact of entrepreneurial education and entrepreneurial intentions as well as the entrepreneurial ecosystem in VET (Vocational Education Training) in Romania for establishing whether the moderate behavioral traits on entrepreneurship can positively and significantly influence young people's entrepreneurial intention. Entrepreneurial education, as a sustainable process, is the support of innovation, which leads to the efficient use of resources. Entrepreneurship involves change and novelty, and one of the reasons it should be encouraged is that "what is different is not always better, but what is better is always different" [7,8]. A positive attitude towards entrepreneurship means a desire to exploit opportunities, with individuals changing the future of their society by changing their own vision of their societal role. The European Union promotes entrepreneurial spirit as a key factor for competitiveness, which represents the importance of implementing and developing a true entrepreneurial culture at the member state level. Entrepreneurship is the most powerful economic force of mankind because entrepreneurs are people who recognize opportunities where others see chaos or confusion and are aggressive catalysts for market change. Entrepreneurship is more than just creating a business-it is taking risks beyond security and having the tenacity to push an idea through reality. Entrepreneurship is the symbol of tenacity and business achievements, and as such, entrepreneurship is an aggressive catalyst for change in the business world $[7,8]$.

\subsection{Theoretical Context for Entrepreneurship and Entrepreneurial Eco-Site}

Entrepreneurship began to receive attention with the problems brought about by the global economic and financial crisis, and entrepreneurs became heroes capable of providing a boost to fragile economies. Entrepreneurship cannot be accurately defined, and the multidimensionality and homogeneity of the concept make it very difficult to generalize the conclusions of studies on this concept. The main characteristics of entrepreneurship are innovation, proactivity, and risk-taking, and these positive effects are associated with entrepreneurship, directly or indirectly: sustainable development, the overall growth 
of business performance and economic efficiency, creation of new jobs, improvement of regional and national competitiveness, more efficient management of economic crises, and recognition and exploitation of opportunities [9].

Both researchers and people involved in economic policymaking and development strategies are increasingly emphasizing the role of entrepreneurship in ensuring the economic growth of a country. Entrepreneurship has come to be associated with economic development and the well-being of nations. This statement is supported by a number of researches in the field, such as those conducted by Fernandez-Guadaño et al. They performed an analysis of the population's skills in the managerial field, starting from the traditional business model, demonstrating the usefulness of increasing the individual level of managerial, entrepreneurial competence. The purpose of this growth is to support individual progress because there is a clear relationship between it and the increase in the level of entrepreneurial competence [10]. Research by Buzu and others in this area, taking an approach in conjunction with the circular economy, provides additional evidence. The authors' study proves that the use of circular economy processes is felt at the individual level. Specifically, there are clear benefits in terms of quality of daily life [11].

The particular importance given to entrepreneurs in their studies on economic growth is explained by the fact that they are the ones who introduce new technologies, promote new products, stimulate the discovery of new resources, and mobilize capital. An example with proven relevance is provided by the study conducted by Briciu et al., who analyzed the influence of the use of innovative technologies in tourism entrepreneurship, proving that this approach leads to improved results in this field. Essentially, the avant-garde technology increases the attractiveness of the tourist offer [12]. Meanwhile, going on an even more interesting path, Bican et al., in agreement with the changes that are taking place worldwide regarding digital transformations, analyzed the implications of these transformations in entrepreneurship. The authors discuss the sustainability of digital entrepreneurship, presenting an extremely favorable perspective on this type of entrepreneurship [13].

Public information amply proves that entrepreneurs are the ones who provide jobs for most of a country's population, which consolidates the middle class. Research on family entrepreneurship presents very clear evidence of the importance of this social segment. Schepers et al. conducted an analysis at the level of family firms that established a clear link between the long-term orientation of the family and entrepreneurship. The authors' study analyzed how the disappearance of family members clearly affected the firm [14]. As a link, in terms of entrepreneurs' attitudes towards the environment and the legislation governing their business, Keiko Yamaguchi et al. looked at family businesses in agriculture, proving the importance of training entrepreneurs [15].

\subsubsection{Analysis of the Entrepreneurial Ecosystem}

Various definitions for the term entrepreneurial ecosystem can be found in the literature, all of which are that it encompasses the social and economic environment affecting entrepreneurial activity. The concept of an entrepreneurial ecosystem highlights the collective and systemic nature of entrepreneurship. Therefore, in order to stimulate entrepreneurial activity in a particular country, it is necessary to facilitate the creation of an ecosystem conducive to entrepreneurship. The approach of entrepreneurship based on personal attributes is explained by the fact that not everyone is willing for entrepreneurial activity. CarrilesAlberdi et al. analyzed the influence of the entrepreneurial ecosystem and highlighted important aspects, namely that people with higher education have a greater inclination towards entrepreneurship. The authors also found that in countries based on innovation, women are more easily incorporated into the entrepreneurial phenomenon [16]. Also, a large part of potential entrepreneurs never starts entrepreneurial activity, or shortly after starting their business, they abandon it. In order to identify the stage of new entrepreneurs, entrepreneurs are divided into four categories in the Global Entrepreneurship Monitor (GEM) study [17]. In order to bring real input to a country's economic development, it is necessary for newly created businesses to become persistent, to exceed 3.5 years of 
activity, during which the newly created businesses are unstable and threatened by the risk of discontinuity. At the same time, both the willingness of a country's population to start businesses, as well as the ability to go through the entrepreneurial stages as from potential entrepreneur to entrepreneur with 3.5 years of experience, depend on multiple environmental factors, such as access to financial resources, government policies, tax facilities, government and non-governmental business support programs, entrepreneurship education and training, access of small businesses to Research and Development (R\&D) activities, business infrastructure as well as cultural and social norms. In other words, the intensity and persistence of entrepreneurial activity are subordinated to the quality of the entrepreneurial ecosystem characteristics of that country.

Creating an entrepreneurial-friendly ecosystem is an extremely difficult task because the ecosystem is made up of multiple elements. Entrepreneurial ecosystems have become the object of research of governments, development agencies, and academia. Kim et al. have highlighted in their research that it is very useful for educational institutions to create a social entrepreneurial ecosystem. The advantages of such an ecosystem are brought to other entities that need more active interactions [18]. Organizations such as the US Competitiveness Council (COC), the GSM Association, the Organization for Economic Cooperation and Development (OECD), the World Bank, and the World Economic Forum have developed complex tools for assessing and tracking ecosystem development. In addition, there are models for assessing ecosystems developed by investors. The relevant models for evaluating entrepreneurial ecosystems are Babson Entrepreneurship Ecosystem ProjectBabson College, Asset Mapping Roadmap-Council on Competitiveness, USA, Global Entrepreneurship and Development Index-George Mason University, Innovation Rainforest Blueprint-Hwang V.H., Six + Six-Koltai Company, Information and Communication Technology Entrepreneurship, Entrepreneurship Measurement Framework-OECD, Doing Business-World Bank, and Entrepreneurship Ecosystem-World Economic Forum [19,20]. Each of these entrepreneurial ecosystem evaluation models is based on multifactorial analysis, e.g., the model developed by Babson University involves investigating the simultaneous state of 13 distinct domains, where at the center of the ecosystem is the entrepreneur, who carries out entrepreneurial activity, but his activity is accelerated or, on the contrary, braked by the ecosystem. Each of the 13 spheres that form the ecosystem generates favorable factors or impediments to entrepreneurship. The entrepreneurial ecosystem in Romania is developing, although the country has a lot of potential, and the dynamics of the changes needed to promote an innovative economy and a digital society are quite small. Expert assessment of the current state of the entrepreneurial ecosystem indicates that the biggest barriers to its development are lack of confidence, predictability, and transparency, as well as access to funding and the limited capacity of educational institutions to play an active role as a stakeholder in the entrepreneurial ecosystem. The entrepreneurial ecosystem in the Babson University approach is relevant for this [21].

In addition, inadequate communication between ecosystem stakeholders and poor coordination of government decision-makers slows down the ecosystem's evolving process. Undoubtedly, there are islands of excellence, so access to a supply of talent with an adequate education is one of Romania's greatest strengths. Bratucu et al. managed to establish a link between regional development and sustainable development of universities through an analysis conducted at Transilvania University of Brașov. This aspect is seen from the purely economic perspective of the aforementioned relationship. The inclusion of entrepreneurial training for students, the creation of business incubators, and student entrepreneurial societies represent, in the opinion of the authors, the chance to develop the universitystudent ensemble. The result, which is important for the future, is to provide young people with the necessary support to work in the entrepreneurial field [22]. However, brain migration, insufficient funding opportunities, and reduced entrepreneurial culture at the secondary level of education require radical policy measures to make the current state of affairs change more quickly. [23] The COVID-19 pandemic highlighted another important aspect. Barbulescu et al. analyzed the need for business development and restructuring on 
a sustainable basis in the context of the COVID-19 pandemic. The authors' research allowed them to conclude that it seems necessary to involve entrepreneurs in this restructuring process. It seems that collaboration between companies, the public sector, academia, and society, in a quadruple spiral, can ensure targeted sustainable development [24].

\subsubsection{Motivations for Entrepreneurship and Barriers for Young Entrepreneurs}

To maintain the research problem on entrepreneurship, a narrow definition of entrepreneurship can be used, which focuses on the objective of generating income, i.e., those people who are entrepreneurs, want to become entrepreneurs, or want to start a new business, either in the formal or informal sector, to generate income.

For this purpose, this study is based on youth entrepreneurship; therefore, the authors did not define a specific age range to focus on for young people, and they keep it as large as possible. This is because the definition of young people's ages varies according to context. For example, official countries and statistics define young people in different ways, so setting an age range causes problems in terms of data comparability. Similarly, different organizations define young people differently, so reducing young people to specific age can render this project inappropriate for some organizations unnecessarily. For example, the YBI defines young people up to 35 years of age, while the UN defines young people between the ages of 15 and 24. Moreover, there are more entrepreneurs in the 25 to 34 age group than any other age range (GEM 2011), which suggests that a wider age range, e.g., if the age of 35 is used as the highest age, will include a fairly large portion of all entrepreneurs and will therefore allow conclusions to be drawn from the general literature of entrepreneurship and from the data for young entrepreneurs.

It is important to recognize that not all entrepreneurs are the same. Therefore, the authors believe that young entrepreneurs will present a variety of individual factors or profiles, which may create different needs for support interventions for young people's entrepreneurship between these groups. Several studies explore different ways of classifying young entrepreneurs. For example, Chigunta (2002) proposes a transitional classification in three age groups: the formative stage of pre-entrepreneurship (15-19 years), the growth stage of budding entrepreneurs (20-25 years), and the primary stage of the emerging entrepreneur (26-29 years). Lewis and Massey [25] provide a more diagnostic framework for young entrepreneurs. As described by Schoof [6], the paper distinguishes four types of young entrepreneurs along a continuum of the level of training, e.g., the level of skills and exposure to the enterprise, the young entrepreneurs (potential), and the level of intention to engage in entrepreneurial activity. These types of models can provide some information about the specific needs of different groups of young entrepreneurs and about how to prioritize appropriate interventions to maximize the impact according to the needs of that group profile; however, the authors need to focus this study on terms of disaggregation.

To get a more specific view of potential young entrepreneurs, Lewis and Massey [25] provided a diagnosis framework for young entrepreneurs. It depends on young people's level of training to engage in business and the level of intention to be an entrepreneur. The authors distinguish four different groups of potential young entrepreneurs. This type of framework can help researchers and those who are policy-makers better understand the special needs of young people as a group and identify appropriate methods and promotion programs in order to improve the entrepreneurial ecosystem in a selected country or region [25]. There are five factors that influence youth entrepreneurial engagement to encourage youth entrepreneurship. This includes the following: social and cultural attitude towards youth entrepreneurship, entrepreneurial education, access to funding or starting funding, administrative and regulatory framework, and business support and assistance [25].

The social and cultural attitude towards youth entrepreneurship refers to cultural and social environments that influence an individual's approach to life and similarly influence entrepreneurship and enterprise culture. Gibb defined an enterprise culture as a set of 
attitudes, values, and beliefs that operate within a community or environment that lead to entrepreneurial behavior as well as the aspiration of self-employment [26].

Researchers have long realized that cultural attitudes influence the entrepreneurial activities of a population, country, region or ethnic group, and they interact as well. Thus, cultural differences between nations are increasingly understood as important to a nation's level of economic and entrepreneurial development. In a cultural environment in which entrepreneurship is respected and harnessed, business failure is treated as a useful learning experience rather than as a source of stigmatization [27].

Cultural perceptions of entrepreneurship depend on additional factors. First, young people need to have perspective and exposure to social problems in need of successful models. Entrepreneurial education and the competitiveness of a country does not start from the factory or in an engineering laboratory-it begins in the classroom [28]. This is important to help young people develop entrepreneurial skills, attributes, and behaviors and for enterprise development and, most importantly, to understand and achieve entrepreneurship as a career option. Thus, entrepreneurial education is not only a means of encouraging young people to become independent, but it is an opportunity to develop the attitudes, defined as personal responsibility, and skills, defined as flexibility and creativity, needed to cope with the employment barriers in today's societies. Entrepreneurial education becomes a support for environmental aspects. Oncioiu et al. analyzed the possibility of modifying business processes in the green field and regarded the effectiveness of these measures [29]. Another argument is provided by Cárcel-Carrasco et al., who analyzed the influence of industrial maintenance on the strategic planning of companies, concluding that it exists and resides in better economic results [30].

The lack of adequate financing to start a business is one of the biggest barriers and impediments for young people who want to start their own business. The lack of funding was also considered to be a more severe barrier than the administrative framework and administrative regulations. Administrative framework and regulations on youth and business entrepreneurship is generally a fairly new area of research. However, these tasks are among the most important barriers to starting young businesses. Government regulations and bureaucratic formalities are also seen as a reason for the large informal sectors in many developing countries because formalization costs are higher than productivity gains. Entrepreneurs also face numerous administrative burdens, including companies registering, tax administration, obtaining investment approvals and commercial licenses, compliance with copyright and patent regulations, competition law, access to workspace and long-term rentals, building and construction permits, customs clearances, utility connections, etc. Business support and business consulting services are very useful for a young entrepreneur because more business support at the beginning and early stages encourage lasting success. These youth support services are mentors, business clubs, and business incubators. These support services can hold the key for transforming youth start-ups with one person into successful small and medium-sized enterprises [31]. This statement is also supported by research conducted by Ibáñez García et al., who analyzed students' perceptions of training through mentoring programs. The authors found that the benefits are very high, with students highlighting the mutual benefit of mentoring [32].

In conclusion, there are various reasons why young people decide to start a business, in relation to their life circumstances, attitudes, preferences, personal goals, interests, and individual strengths. Recognition of these reasons is crucial for understanding and stimulating young people's entrepreneurship.

\subsubsection{Theories of Entrepreneurial Intentions}

The first formal theory about entrepreneurship was developed by Richard Cantellon in 1725 [33]. He defined entrepreneurship as those self-employed people who take the risk of buying at certain prices and selling at uncertain prices. Later, in 1803, the definition of entrepreneurship was extended to include factors of production, where an entrepreneur 
transferred resources from locations where they exist in places where there is a shortage of those resources [34].

None of these definitions explicitly captures the trait Josef Schumpeter considers "sine qua non" (without which you cannot) in becoming an entrepreneur of success, i.e., innovation. In his vision, an entrepreneur is a person who develops new technologies and products that change the environment in which they operate, create new opportunities, and change the way of thinking and operating in a particular field of social activity. It is worth noting that Schumpeter saw the entrepreneur not as an inventor of new products but as an explorer of new opportunities that lead to innovation. Together, these three definitions contribute to a common idea of entrepreneurship: risk-taking, coordination, and innovation [35].

The entrepreneurial intentions of individuals are the most important variables that predict their entrepreneurial behavior. Referring to the entrepreneurial intentions of individuals, the current literature adopts several concepts such as career orientation [36], budding entrepreneurs [37], etc. One of the main theoretical works that guided research on entrepreneurial intent comes from the Theory of Planned Behavior [38], according to which the intentions that precede any type of planned behavior are determined by three factors: attitude towards behavior, subjective norm, and control of perceived behavior. Indeed, most models of entrepreneurial intent rely on Ajzen's model, arguing that both psychological and behavioral variables are important in fixing entrepreneurial intent. Political and economic factors, as well as the social context, such as social support, subjective norms, and the perception of opportunities and resources, can also contribute to the formation of their intention to be their own employee [38]. This aspect of the social context was an argument for García-Jurado et al. The authors analyzed the entrepreneurial field, considered to be an emerging field, under the influence of the millennial generation, much more connected to technological progress. The authors found that this influence takes on the appearance of a phenomenon over the millennia and a growth factor of entrepreneurial intent [39].

Shapero and Sokol's theory of entrepreneurial event argues that bad business is the result of interaction between contextual factors that act through their influence on individual perceptions. There are two types of perceptions: perception of desire that refers to the degree the individual feels attracted to the given behavior (to become an entrepreneur) and perceiving the possibility of realization, which refers to the extent to which people consider themselves personally capable of exhibiting a certain behavior [40]. Shapero and Sokol believed attitude is closely linked to entrepreneurial intent, particularly the perception of feasibility and opportunity, and that attitudes derive from the previous exposure to entrepreneurial activities, including both the scale and positivity of previous activities [40].

The first courses on entrepreneurship began in the United States in the 1940s. Then, entrepreneurship education increased considerably around the world. One of the four strategic objectives of the Strategic Framework for European Cooperation in Education and Training, approved by the Council of the European Union in 2009, is to increase creativity and innovation, including entrepreneurship, at all levels of education and training. In this respect, the basic knowledge acquired through entrepreneurial education involves the following: determining opportunities, formulating opportunity through the creation of new ideas and the mobilization of the necessary resources, building and managing a new business, and developing creativity and critical thinking skills [41].

Drucker considered that entrepreneurship is a discipline [42] and for the bigtime, entrepreneurship plays a key role in improving the skills of potential entrepreneurs and their orientation towards the ability to create, develop, and maintain new businesses. Research in this area has shown that through entrepreneurship programs, young people develop entrepreneurial attitudes and skills. Additionally, different educations and skills can explain why some people are engaged in entrepreneurial activities and enjoy more success than others, and students enrolled in these programs can be future entrepreneurs. It is important that educational support is tailored based on their needs and desires to 
learn and achieve. About this, Lu et al. analyzed the entrepreneurial support university students received and whether it influenced their entrepreneurial intention. It was found that the perception of students was largely positive, which led the authors to conclude that it is necessary to create a stronger entrepreneurial climate at the university level. It also demonstrates the usefulness of organizing entrepreneurship competitions, in addition to entrepreneurship courses [43].

Education is vital to understand entrepreneurship, to develop entrepreneurial skills, and to contribute to their entrepreneurial identities and cultures on an individual, collective, and social level. The need for entrepreneurship education is a certainty. Butum et al. investigated students' perceptions of the skills they acquire and their perspective of their professional future and concluded that they have very well-defined opinions about their need for knowledge [44]. Therefore, an individual who receives an entrepreneurial education that provides him with the necessary administrative skills will be engaged in entrepreneurial activity in the future. This educational component has additional value, correlated with the professional path of the people. This aspect is revealed by Cioca et al., who studied the level of correlation of the profile of young people enrolled in higher education programs. This aspect is very important because many young people change their field of study along the way, which prejudices the educational system, the state that supports the educational component. There is an explicit need for support in career guidance for young people, as almost a third of students choose careers that do not coincide with their interests [45]. Over time, studies have shown that there is great efficiency in education, leading to an increase in the number of entrepreneurship programs in the education system through various forms. Frolova et al. have also researched ways to increase the effectiveness of entrepreneurial education. The authors' analysis led to the conclusion that a new approach to motivating students is needed. The research is valuable because it generates motivation models that can be applied later in the field of human resources [46]. It has also been observed that entrepreneurial skills and intentions can be easily learned with the help of provided educational support that is based on practice, as Bratucu et al. have shown [22]. In addition, since knowledge consolidation should not be ignored, the study by Yuan et al. proves the usefulness of entrepreneurial education. The authors conducted an empirical analysis comparing entrepreneurs and employees with higher education. The authors found that entrepreneurs have a much greater concern about adding skills to their existing baggage. This conclusion comes with the condition that it is proven they have an additional level of stress as a result of the activity they carry out [47].

\subsection{Entrepreneurship in Romania}

In recent decades, after the 2008-2009 economic crises, the importance of entrepreneurship for economic growth and development at a global level has been a topic that has captured the interest of researchers and practitioners, due to the multidimensional aspects of the phenomenon, with microeconomic and macroeconomic implications [48]. The European Union's entrepreneurship policy constantly highlights the need to create the most appropriate micro- and macro-environments to support the development of smalland medium-sized companies and entrepreneurship. The opinion on the entrepreneurial ecosystem for the former communist countries is that they are behind other European countries, and the differences between the East and West are obvious when the performance of start-ups is analyzed. However, Romania has a strong entrepreneurial ecosystem despite the low level of economic development. Entrepreneurship is valued in society, and $48 \%$ of the working population prefers to develop their own business, according to Global Entrepreneurship Monitor data, compared to the European average of $37 \%$. The preference for entrepreneurship could be explained by the low level of wages in Romania, in which context people have higher potential incomes by going on their own. An important aspect is also offered by the social specifics of Romanians, as can be found from the conclusions of the study conducted by Hatos et al. on the individual approach to entrepreneurship in Romania. The authors conclude that individualistic approaches are not specific to people 
who can become entrepreneurs [49]. However, half of the Romanian respondents say they do not have the financial resources to develop their own business, more than double that of the European Union, where $21 \%$ of the respondents say that lack of money is the reason why they do not develop their own businesses.

The Global Entrepreneurship Monitor (GEM) measures entrepreneurial activity through seven indicators: the rate of entrepreneurship in training, the rate of start-ups, the total entrepreneurial activity (TEA), the stable business rate, the rate of business discontinuation, the rate of entrepreneurship motivated by need, and the rate of entrepreneurship motivated by opportunity. The main indicator used by the GEM to measure entrepreneurial activity in a country is the Total Entrepreneurial Activity (TEA), which is an indicator representing the working population between the ages of 18 and 64 years who are in the process of starting a business (entrepreneurship rate in training-nascent entrepreneurship rates) or already running their own start-ups (rate of newly established companies-new business ownership rates). The TEA indicator for Romania is $9 \%$, one percentage point higher than the European average, which ranks it sixth in Europe in terms of total entrepreneurial activity after Austria, Estonia, Latvia, the Netherlands, and Slovakia. The TEA structure is similar in Romania and the EU, with the rate of entrepreneurship in training representing about $60 \%$ of the total entrepreneurial activity [50].

The stable business rate measures the percentage of the common path at cross the start-up threshold and reflects the sustainability of entrepreneurship in a country, and the businesses that reach this level are the ones that innovate and create new jobs. In general, the TEA is high in developing countries, but the newly established business can do not last over time. This is also the case of Romania, which is placed in the penultimate place in the $\mathrm{EU}$, in terms of company sustainability having a stable business rate of $4 \%$ for over $50 \%$ of entrepreneurial initiatives. In Romania, $25 \%$ of entrepreneurial activity is driven by need, and $38 \%$ of them takes place to spread the opportunities encountered on the market. The situation is consistent with Romania's status as a developing country; thus, Romania has more entrepreneurs motivated by need compared to the European average, and a lower percentage of people motivated by market opportunities (38\% compared to the European average of $47 \%$ ). In Romania, there is an upward trend in the rate of entrepreneurs in the process of being formed and also in the importance of the entrepreneurial programs and educational support offered by the Romanian education system, as was shown in the rate of trainee entrepreneurs in Romania in the GEM [17].

Compared to other countries of the European Union, this rate is a small one, but it is nevertheless appreciated that the emphasis is on promoting entrepreneurship and supporting young people's educational support in order to be able to move towards a future career as entrepreneurs. Entrepreneurs' aspirations and their prospects for the future of their own businesses are important because they show the degree of reding in the ecosystem in which they operate. International education shows the percentage of TEA for companies that have at least $25 \%$ of their clients outside the country's borders. The new product rate reflects how innovative a start-up is and predicts the percentage of a business in TEA that claims that the product or service it offers is none for at least some customers. Finally, the expectations of further growth show a company's future development prospects and are calculated as the percentage of TEA that estimates they will employ at least 5 people over the next 5 years.

Significant improvements were also recorded in the informal investor rate, measured as a percentage of the active population that provided financing for a start-up set up by a third person in the last three years. In the absence of a solid ecosystem to finance new businesses, this rate is important because it shows the willingness of the population to invest in start-ups [51].

Romania is among the first European countries where entrepreneurial intentions are high in the whole society. The positive attitude towards entrepreneurship influences the probability of becoming an entrepreneur and the level of support that new companies will receive, whether it is access to finance, partners, or mentors. So, $71 \%$ of Romanians consider 
entrepreneurship an excellent career alternative compared to only $58 \%$ of Europeans. Additionally, $74 \%$ of the Romanian population believes that entrepreneurs have a privileged status in society. In Romania, there was a decrease in entrepreneurial activity, and also, after 2015, Romania is no longer found in the GEM reports. This process of declining entrepreneurial activity is most likely caused by combined reasons, which have been unfavorable to the entrepreneurial intent. Statistics at the European level indicate that Romania allows little importance to entrepreneurial education, so that less than $10 \%$ of those who have started and developed a business have a theoretical basis for this, compared to the European average of $30 \%$. In this regard, Romania being a member of the European Union. Antohi et al., starting from the need to understand the sustainability of the absorption of European funds, analyzed, among others, the error phenomena that affect the absorption rate. Starting from the audit role, the authors come to establish the relationship between the professional level of entrepreneurs and the sustainability of the absorption of European funds [52,53]. Approaching another perspective, Paunescu et al. analyzed the Romanian entrepreneurial environment to understand the component of entrepreneurial intention. The authors demonstrated that, in Romania, the incentives for entrepreneurship could be offered by the technological availability and stability of the rules [54]. This demonstration, touching on the delicate subject of rule stability, provides another reason for the decline in entrepreneurial activity. It cannot be ignored that the result of research conducted by Costache et al. analyzed the factors that affect Small and Medium Enterprises (SMEs) and correlated with them, the decision factors involved, highlighting the positive and negative aspects. Adaptation to the context is what allows SMEs to be successful in their business. In this way, another reason is revealed, this being the ability to adapt [55].

From Global Entrepreneurship Monitor [17], the authors identify the entrepreneurial behavior and attitudes in Romanian entrepreneurial framework conditions. The GEM study examines the characteristics, motivations, and ambitions of people starting businesses, as well as social attitudes towards entrepreneurship. First, the employment rate of the population aged 20 to 64 in Romania (63.9\% in 2013) is lower than the EU average (68.5\% in 2012), with a national target of $70 \%$ by 2020 . Second, problems arise, however, when the sustainability of the Romanian entrepreneurial environment is analyzed in terms of total entrepreneurial activity, with $9 \%$ of the active population being in the stage of start-up or pre-start-up, over $50 \%$ of the newly established initiatives do not survive the critical period. In this context, the focus should be on the development of entrepreneurship education in the education system, either pre-university, university, and all parts of life.

\subsection{Attitudes and Perceptions from the Perspective of Technological Entrepreneurship}

The idea of introducing entrepreneurship into education and stimulating entrepreneurship could result in a multitude of effects, such as economic growth, the workplace creating and increasing the social resilience of and from individual growth, school involvement, and improving equality. This aspect is also supported by the results of the research by Manning et al. They researched the importance of including entrepreneurship training programs for agricultural specializations. The authors point out the need to develop a new conceptual spiral pedagogy to improve teaching in agricultural schools. It reaches the training in the eco-entrepreneurial field, and it is very useful as a border element for specialist managers in agriculture [56]. In this regard, the need for regional sustainability has led Hagebakken et al. to study the possibility of using entrepreneurial education to build this sustainability. Although the long-term impact of entrepreneurship education is difficult to determine, the authors prove the usefulness of this type of education through analysis among Nordic start-ups in Norway [57]. The implementation of this idea, however, has posed significant challenges alongside the declared positive effects. A lack of time and resources, fear of teachers changing, prevention of educational structures, evaluation difficulties, and a lack of definitional clarity are some of the challenges practitioners have faced when trying to implement entrepreneurship and technology in education. 
The European Commission's Entrepreneurship 2020 Action Plan, published in 2013, mentions the importance of focusing on developing cross-cutting and entrepreneurial skills in order to improve the employability of young people. Technological entrepreneurship does not refer to a single individual or the inventions they introduce. It is about managing common exploration and exploitation, in which each individual has roles and responsibilities in terms of progress, and also in collaboration and cooperation with achieving common objectives [58]. Technological entrepreneurship refers to the investment and execution of firms' projects, not just to the recognition of technology or market opportunities. Entrepreneurship-related skills and perceptions are analyzed by the Global Entrepreneurship Monitor using seven indicators: the perception of business opportunities, the perception of one's own skills, the fear of failure in entrepreneurship as a career alternative, the status given to successful entrepreneurs, and the attention given to entrepreneurship. The authors analyze the situation of these indicators for the 27 European countries, together with the arithmetic average for each of them. From the entrepreneurial attitudes and perceptions in EU countries, Romania registers values higher than the European average for most indicators. This is also supported by the fact that studies have shown there is a direct relationship between the perception of one's own skills and competencies on the one hand and the level of economic development of a country on the other [50].

Romanians are prone to risk, and that is why the fear of failure is higher than the European average (41\% compared to $39 \%$ at the European level). Romania is the first country in Europe in terms of entrepreneurial intentions because $27 \%$ of Romanians claim they want to start their own business. This aspect is also relevant in the context in which Romania is one of the post-transition economies, which was targeted by the study of Voda and others. They conducted research in post-transition economies and demonstrated a relationship between individuals' income levels and entrepreneurial intent. People with higher incomes are the most inclined to start an entrepreneurial activity. The novelty element is conferred by the fact that the previous barrier was overcome, according to which the entrepreneurial intention was discouraged by the existence of some relational connections, or other support elements of the individuals, to encourage this intention [59]. The important thing is to study attitude in any context because attitude could greatly affect a person's behavior, and a model of attitude in relation to behavior is proposed by Fishbein and Arjen [60].

This theory holds that attitudes towards behavior, including that of entrepreneurship, predict intentions that in turn predict real behavior; however, it is debatable to agree that a potential entrepreneur should first develop an attitude towards a new enterprise, and this attitude will lead to the intention to initiate a start-up. If the intention of such an initiative is strong, the entrepreneur takes steps in turning it into action. As it can be seen, the value or expectations held by an individual related to the individual's beliefs about an object or event constitutes the basis for the development of the attitude, either positive or negative, towards the object or event. This is transformed into intentions and, consequently, into behavior towards the event or object, including that of the creation of enterprises [61].

The measures necessary to improve entrepreneurship can be taken at both the public and private levels. As a result of the study, the authors believe that there should be a clear division of responsibilities at the government level, so the state should focus on improving the quality of entrepreneurial education programs and, in this respect, there should be a close link between school and business, and the curriculum should be adapted to market conditions [62-64].

The transition from the traditional innovation system to the new philosophy-open, expanded, and collaborative innovation-has multiple causes. This transformation is the result of changes that occurred in the business environment and in society, while the airing of competition and accelerating technical, scientific, and social progress leads to technological entrepreneurship. Among the factors that have contributed to this, new concepts in innovation can be remembered: the increase in R\&D spending, with the effort being difficult to sustain even by large companies, increasing complexity of the problems 
facing humanity, requiring collaboration and convergence of forces to reduce risks, and increasing R\&D's completion speed of development and innovation projects [65].

\subsection{Entrepreneurship in Vocational and Technical Education in Romania}

Since 2009 the Council of the EU, where the Council of the EU and representatives of the Governments of the Member States on the development of education in a fully functional knowledge triangle, have proposed an attitude for promoting a creative, innovative and entrepreneurial perspective among students, teachers, and researchers, which would support the progressive development of a broader entrepreneurial culture through vocational education and training, as well as a more dynamic European labor market and a more skilled workforce. In an educational system that is meant to be modern and in close connection with the needs of a society, the pre-university education level should keep up with all the novelty elements required by this evolution. The teaching method, approved by the Romanian Ministry of Education (MEC) in partnership with the National Center for the Development of Vocational and Technical Education (CNDIDT), on the exercise firm implemented at the level of vocational and technical education in Romania aims to facilitate the transition from school to the active life of students and to integrate students more easily to the future status of employee or employer of a company simulating the processes of a real company [66]. Students and coordinating teachers will work together in virtual firms, firms created by students and monitored by those authorized to run the program, the CNDIDT structure. For this, the correlation between innovation and entrepreneurship becomes mandatory. In this regard, Anser et al. have proven that technological innovation is a relevant aspect in supporting the entrepreneurial component. Innovation as a component of technological education is the element that supports the achievement of efficiency in the correct development of processes in an organization [67].

In this context, a broad, modern approach to the concept of entrepreneurial education and entrepreneurial skills should be connected to today's social needs, and this must analyze entrepreneurial education in terms of status, skills, content, and values in order to advance the proposals on improving entrepreneurial skills in Romanian vocational and technical education (VET) [68]. In order to establish an accurate picture of entrepreneurial education in Romania, in terms of concept and status, the authors have analyzed relevant curricular documents such as elementary, secondary, and high school education plans and curricula from secondary and high school subjects at the national level. After analyzing all the elementary, secondary, and high school study plans, the authors found that entrepreneurship education does not appear as a separate topic in the curriculum, either at the primary or secondary level, even though it is the subject that could best contribute to the realization of one of the eight key European competencies with the aim of initiative and entrepreneurship [69]. Students learn entrepreneurship education only in grade 10, one hour a week, and in grades 11 and 12 in technological high schools only, while in the service profile, they still study entrepreneurship through the interactive method of the exercise firm. With this method, the practice firm was meant to train the beneficiaries practically in the field of information processes, broadening their field of knowledge in a field of vocational training, which the mandatory curriculum does not provide for this activity. Through the vocational evaluation and advice program, as well as through the specific activities of the exercise firm, students identify optimal areas of professional development and acquire basic skills in the field of commercial, financial-accounting, human and legal resources activities, as well as teamwork. The use of these tools increases the success rate in employment and the creation of new jobs. The results obtained by using these tools are affected by the media's influence. Regarding this component, Yasir et al. showed through their study that the media's consequences on attitudes towards sustainable entrepreneurship. The authors clearly demonstrated the importance of supporting talent in this field and increasing entrepreneurial skills [70]. 


\subsection{Entrepreneurship Intentions in the Romanian Business Market}

The 2020 COVID-19 crisis had a terrible impact on the number of newly created companies, producing a decreased of $60 \%$ between March and May compared to the previous situation. Therefore, 2020 has a very good chance of being the year with the fewest companies established in the last 15 years for Romania, but probably for Europe as a whole. From an average of 12,000 to 14,000 new companies per month, April 2020 brought only 2500 newly created companies.

That is why the authors have used the 2019 data. The number of Romanian Small and Medium Enterprises (SMEs) at the end of 2019 was 723,604, where the number of SMEs from the Center region represents only $11 \%$ of the total number [71].

However, from the whole number of Romanian SMEs, an important percent is represented for the Romanian economy by the startup companies created with non-refundable financing. These are companies created during the last ten years, but especially in 2017-2019, financed through two different programs called Start Up Nation and Romania Start Up Plus, first financed from the Romanian budget and the second from the EU budget. Both programs offer around 40,000 non-refundable euros, which represent 200,000 lei.

Start-Up Nation Romania (SUNR) was a great success, given the fact that in the competition, 18,000 companies applied in 2017, respectively, 33,000 companies in 2019, and more than 8500 companies were beneficiaries in 2017, and in 2019 approx. 10,000 companies received funding. Therefore, it is considered that in the world of non-reimbursable funds, Start Up Nation has aroused the greatest interest in the last 10 years [72].

The second entrepreneurship scheme financed by Human Capital Operational Program (POCU), called Romania Start Up Plus (RSUP), was also a success, with over 8700 new businesses were set up through these financing lines, within the 205 projects implemented by the grant administrators selected by the Ministry of European Funds. Most start-ups financed from European funds through RSUP are in the Center region, numbering 1562 [73].

On average, the age of successful entrepreneurs is closer to 40 years than 20 years, and this is confirmed from an analysis carried out by the National Council of Small and Medium Private Enterprises in Romania, which concluded that most of the beneficiaries of these entrepreneurship non-refundable financing schemes are not very young entrepreneurs that are around 31 to 45 years and have an entrepreneurship education. Additionally, in the center region of Romania, many young entrepreneurs were beneficiaries of more than 1000 grants offered through SUNS and RSUP, so the authors conclude that entrepreneurship education was decisive in starting a new business [74].

We can conclude that the Romanian center region can be used for the 2018-2020 period as a relevant region for studying the education and the entrepreneurial intensions in the Romanian business market.

\section{Methodology of Study}

According to Zikmund, the survey is the best method available to a researcher when the objective of his research is to assess the opinion or perception of his respondents on issues of interest and at some points in time. This research aims to determine the influence of cultural values and entrepreneurial preparation on students' intention to engage in future entrepreneurial practices [75]. The research methodology used for this study was the questionnaire, and the longitudinal method applied involves the research of a group of young people in VET education and ends in a school year. The questionnaires measured the students' opinion of entrepreneurship courses offered by pre-university education and the students' intentions to engage in entrepreneurship in the nearest future.

For this study, the authors proposed the following hypotheses:

Hypothesis H1: Pre-university entrepreneurial education positively influences the variables (attitudes and perceptions, motivations and aspirations, entrepreneurial activity) regarding the entrepreneurial intention of students. 
Hypothesis H2: Entrepreneurial education studied in high school in any form positively influences students to become future entrepreneurs.

Hypothesis H3: Young people are influenced by variables (individual characteristics, entrepreneurial culture, funding sources) in the decision to start a business.

The establishment of these research hypotheses required a collection of data based on questionnaires applied to young people in vocational and technical education in Romania and the statistical certification of the causal relationships included. The stages of this research study were as follows: data collection through the questionnaire, preparation and analysis of data, univariate analysis, testing of research hypotheses, interpretation of results, and setting up for conclusions. The scales used to measure constructions have been validated in previous studies. The preparation and statistical analysis of the data were carried out by elaborating the structure of the data matrix, encoding the answers to the questionnaire applied, entering the data into the SPSS application, and verifying the variables. The constructions were measured by 5-step Likert scales, and the data analysis sought to determine the proximity or distance of the distribution of the series of values from the Gaussian distribution by using histograms deviation generated by asymmetry (Skewness) and vaulting (Kurtosis).

The testing of the research hypotheses was done by using multiple linear regression in two steps. Each linear regression directly related to the research model was written in the form of the equation.

$$
Y i=\left(b_{0}+b_{1 \times 1 i}+b_{2} X_{2 i}+\ldots \ldots b_{n} X_{n i}\right)+\varepsilon_{i}
$$

In Equation (1), $\mathrm{Y}$ is the result variable (dependent variable); $\mathrm{b}_{0}$ is the free term of the regression line, $b_{1}$ is the coefficient of the first predictor (first independent variable), $X_{1} b_{2}$ is the coefficient of the second predictor $\left(X_{2}\right), b_{n}$ is the $n$ coefficient of the predictor, and $\delta_{i}$ represents the difference between the predicted and observed value of $Y$ for the participant $\mathrm{i}$. The aim will be to find the linear combination of independent variables that correlate the maximum with the dependent variable.

The assessment of the validity of the tested research hypotheses was made by analyzing the following elements: significance level ( $p$-value), the non-standardized value of the regression function coefficient $(\beta)$, determination coefficient (R2), and the calculated value of the statistical test $(\mathrm{t})$. The coefficient of determination (R2) quantifies the proportion of the variation of the dependent variable that can be explained by the variation of the independent variable. The coefficient of determination (R2) takes values between 0 and 1 . If the value of the coefficient $\mathrm{R} 2$ is close to 1 between the dependent and the independent variable, there is a linear, direct, and very strong connection. The t-test was used to test the regression model's parameters. If the significance level $(p)$ is less than $0.05, \beta$ is significantly different from 0 , and the relationship between the two variables is significant.

\subsection{Population and Sample-Respondents}

The implementation period of the first questionnaire was 90 days, between January and April 2019, with a duration of completion of the questionnaire between 5 and $7 \mathrm{~min}$. The implementation period of the second questionnaire was 60 days between January and March 2020, with a completion time between 7 and $10 \mathrm{~min}$. The target group that was the subject of the research carried out consists of young people and 11th and 12th graders from Romanian technological high schools, who are enrolled in services specialization because those specializations implement the practice firm method and implicitly have several hours of entrepreneurial education in the curricula. The practice firm method is a method of stimulating entrepreneurship among young people in the VET education system. The young respondents are between the ages of 15 and 20, and from the gender point of view, respondents are both female and male.

In this study, the authors set out to evaluate the importance of entrepreneurial education and entrepreneurial activities, as well as determine how the entrepreneurial ecosystem 
influences the entrepreneurial theme for the category of 15 to 20-year-old students in Romania, located in the Centre Region of this country, and included in the pre-university environment (the high school secondary education level). There is little empirical research performed on this topic in Romania, especially on entrepreneurship among young people. The authors started this investigation in the technological high schools of the Central Region, an area considered representative for the entire Romanian vocational and technical education system, based on the fact that the other seven Romanian development regions have the same curriculum in all technological schools for entrepreneurial education. The organizations in the Vocational Education and Technical System in Romania are coordinated by the National Centre for the Development of Vocational Education (CNDIPT), and the students investigated in the authors' study are students from the VET (Vocational Education Training) that are currently enrolled in the compulsory entrepreneurship courses offered by the field of the services. At the time of this study, the population of students in this category was composed of students from the Centre Development Region and were designated as the population of the high school and vocational education study ISCED 3 (International Standard Classification of Education) [76].

The National Statistical Institute of Romania states the total number of Romanian students for the 2018-2019 school year in high school education was 629,000 students. From the whole school population, the share of pupils enrolled in high school education was only $17.7 \%$. Also, in terms of territorial distribution in Romania, $17.7 \%$ of all students were enrolled in secondary schools in the North-East region, $14.2 \%$ from the South-Muntenia region, $12.8 \%$ from the South-East region, $12.6 \%$ from the North-West region, $12.0 \%$ from the Bucharest-Ilfov region, $11.2 \%$ from the South-West Oltenia region, $11.5 \%$ from the Centre region, and $9.0 \%$ from the West region [77]. The analysis uses data obtained through a sociological survey carried out in the Central Region of Romania, which consists of six counties such as Alba, Brasov, Covasna, Harghita, Mureş, and Sibiu, and the authors have demonstrated that this region is a representative sample for the national level. The data collected during 2019 and 2020, through online research, was based on young people that have provided information on entrepreneurship education and entrepreneurial activities during high school learning. Based on this data, the authors started an investigation of entrepreneurship using the youth from the Central Region, which was considered representative of the Romanian education system in the field of vocational and technical education.

\subsection{Instruments \& Investigation Tools}

The population investigated in the authors' study are students and teachers in VET education that are enrolled in the technological Romanian branch, who participate in the compulsory entrepreneurship courses offered by the services profile of this technological branch. At the time of this study, the population of students in this category was made up of students from the Central Development Region and was adopted as the population for the high school study from vocational education (ISCED level 3). The research method used for this study was represented by the questionnaires. In the case of the authors' study, the longitudinal method was applied, which involves the research of a group of young people from VET education and ends in a school year.

In Questionnaire 1, the student questionnaire on entrepreneurial culture and entrepreneurship in the vocational and technical education (VET) system was applied online using Google Forms. The respondents of this questionnaire were students in the 11th and 12th grades from the technological high schools in terms of services in the Central region of Romania. The authors received answers to questionnaires from 159 students enrolled in the 2018-2019 school year. In Questionnaire 2, the student questionnaire on entrepreneurship education in vocational and technical education units (VET) was applied online, using Google Forms, also to young people and students in the 11th and 12th grades from technological high school service profile in the Central region of Romania. The authors received an answer to the questionnaire from 254 students enrolled in the 2019/2020 school year. Finally, in Questionnaire 3, regarding teachers' opinions on entrepreneurship education in 
vocational and technical education units was applied online, using Google Forms, for teachers from technological high schools, teaching in vocational and technical education (VET) in the service profile from the Central region of Romania. In total, 59 teachers responded.

The questionnaires contain several parts: identifying elements on the topic of entrepreneurship, inputting elements on the purpose of this research, questions on the proposed theme, and socio-demographic questions to find out the respondent's profile. The questionnaires also include areas of interest: motivation to be an entrepreneur, experience in entrepreneurship, entrepreneurial culture, sources of funding, psychological traits, attitudes, behavior, and entrepreneurial intentions. All questionnaires received have been interpreted in SPSS (Statistical Package for the Social Sciences), a software for statistical data analysis, and have also been validated or invalidated or processed hypothesis with this software. The authors have also used the Microsoft Excel program from the Microsoft Office package for graphical analysis of the data results from the questionnaires applied to vocational and technical students from Romanian Development Region Center. The research was conducted online, and the respondents are students between the ages of 15 and 20 years.

\subsection{Validity and limitations of the Study}

The authors have demonstrated that these 472 respondents are representatives of the students and teachers involved in teaching activities in the technological branch, service profile high schools from the Romanian center region. They start their demonstration based on the data available from the National Institute of Statistics (NIS) regarding Romanian education [77].

The data from Table 1 demonstrate the importance of the center region in the Romanian education system, based on the regional distribution of students and teachers in different Romanian development regions.

Table 1. The number of enrolled students and teachers in high school by development regions, at the beginning of the 2018-2019 school year.

\begin{tabular}{ccccc}
\hline Romania Region & $\begin{array}{c}\text { No. of } \\
\text { Students }\end{array}$ & \% of Students & $\begin{array}{c}\text { No. of } \\
\text { Teachers }\end{array}$ & \% of Teachers \\
\hline North-Est & 111.666 & $18 \%$ & 9.155 & $17 \%$ \\
South-Est & 80.507 & $13 \%$ & 6.282 & $12 \%$ \\
South-Muntenia & 89.394 & $14 \%$ & 6.986 & $13 \%$ \\
South-Vest-Oltenia & 70.353 & $11 \%$ & 5.882 & $11 \%$ \\
West & 56.935 & $9 \%$ & 5.232 & $10 \%$ \\
North-West & 79.373 & $13 \%$ & 8.213 & $15 \%$ \\
Center & 66.191 & $11 \%$ & 6.491 & $12 \%$ \\
Bucureşti-Ilfov & 75.336 & $12 \%$ & 5.594 & $10 \%$ \\
\hline
\end{tabular}

Romanian high school education includes the following channels and profiles: theoretical branch (humanistic and real profiles) that represent 50\%, technological chain (technical profiles, services, natural resources, and environmental protection) that represent $50 \%$, and vocational chain (military, theological, sports, artistic, and pedagogical profiles) that represent $50 \%$. These courses are meant to help the student in choosing his future career according to affinities.

The technological chain used in our study contains three profiles. The technic profile represents $43 \%$ of the total technological chain, the natural resource profile represents $16 \%$, and our studied profile from the technological branch represents $41 \%$ from the whole technological branch on a national scale.

Based on these two previous percent rate and also on the national student and teacher distribution, the authors assume that the percent of service profile from the technological branch represent $17 \%$ of the total number of high school students, and also based on the 
regional distribution, the number of students and teachers from this profile in the center region is 11.044 respective 767 .

The conclusion is that the 59 teachers that answered the third survey represent $8 \%$ of the total number of technological service teachers from this region (767), and the 472 students that answer to the first and second survey represent $4 \%$ of the total number of technological service students from this region (11.044), and both percentages are representative of the population for the results of the study.

Table 2 present the respondent characteristics of the 472 students that answer to the first and second survey.

Table 2. The number of responses corresponding to the high school service profiles in the Questionnaires.

\begin{tabular}{ccccc}
\hline $\begin{array}{c}\text { Respondents' } \\
\text { Characteristics }\end{array}$ & $\begin{array}{c}\text { Absolute Frequencies (N) } \\
\text { 2020 Respondents }\end{array}$ & $\begin{array}{c}\text { Absolute } \\
\text { Frequencies (\%) }\end{array}$ & $\begin{array}{c}\text { Absolute Frequencies (N) } \\
\text { 2019 Respondents }\end{array}$ & $\begin{array}{c}\text { Absolute } \\
\text { Frequencies (\%) }\end{array}$ \\
\hline Gender & 99 & 39 & 46 & 71 \\
Male & 155 & 61 & & 28 \\
Female & & & 44 & \\
\hline Service field of study (VET) & 59 & 23 & 53 & 28 \\
\hline Commerce & 115 & 46 & 43 & 33 \\
Economic & 56 & 22 & 19 & 13 \\
Tourism & 24 & 9 & 159 & \\
Other profile & 254 & & & \\
TOTAL N & & & & \\
\hline
\end{tabular}

\subsection{Reliability of the Instrument}

After receiving data from the respondents, these data were processed accordingly using descriptive statistics, such as media, module, median, and standard deviation, and they were used in the processing section of the questionnaires, as well as inferential statistics such as Cronbach's alpha coefficient to assess reliability, Pearson $r$ moment correlation, and multiple linear regression. These statistical analysis tools were used to process the questionnaires applied to the target group. To transform the information from the questionnaires applied, the authors used the variables in SPSS: nominal, ordinal variables that are qualitative variables, and the range and ratio variables are of type quantities. To assess the reliability, the Cronbach coefficient was used. As indicated by Sekaran, a Cronbach's alpha coefficient of 0.70 and higher is considered reliable and acceptable [78]. Then, the authors assessed the reliability using Cronbach's alpha coefficient for the variables in Table 3.

Table 3. Summary of processed cases of variables. Reliability Statistics.

\begin{tabular}{ccc}
\hline Variable & $\begin{array}{c}\text { Cronbach's } \\
\text { Alpha }\end{array}$ & $\begin{array}{c}\text { Cronbach's Alpha Based on } \\
\text { Standardized Items }\end{array}$ \\
\hline AP & 0.890 & 0.891 \\
MA & 0.858 & 0.857 \\
AA & 0.893 & 0.892 \\
IC & 0.984 & 0.985 \\
EC & 0.981 & 0.982 \\
SF & 0.995 & 0.995 \\
\hline
\end{tabular}

Note: $\mathrm{AP}$-attitudes and perceptions, MA-motivations and aspirations, AA-entrepreneurial activities, IC-individual characteristics, EC—entrepreneurial culture, and SF-sources of financing.

The information in Table 3 shows that the Cronbach alpha value is 0.984 , which indicates a high level of internal consistency for research with this specific sample of entrepreneurship, and the correlation matrix shows the strength of the association between variables. As can be seen in Table 3, Cronbach's alpha for all variables is well above the threshold of 0.70 recommended by Sekaran, and it can be deduced that the study meets the 
reliability hypothesis. The above results indicate that the four reflective constructs have sufficient reliability.

\section{Results}

The overall objective of the research is to develop a coherent methodological approach, accompanied by the foundation and application of pragmatic tools, for analyzing the entrepreneurship in the VET education system in Romania. Tools that could be extended to the entire education system in Romania. In order to achieve this objective, a coherent set of specific research objectives was detailed, respectively:

Objective 1 Determination of the factors that determine the entrepreneurial intentions and innovation of young people in the VET education system in Romania.

Objective 2 Identification of the entrepreneurial ecosystem in VET education (professional and technical education) in Romania.

Objective 3 Promote a modern approach to the concept of technological entrepreneurship linked to entrepreneurial skills and connected with today's social needs.

Objective 4 Research and improvement of entrepreneurial skills in the Romanian pre-university education system as well as technological entrepreneurship.

Objective 5 Conduct an analysis on entrepreneurial education in terms of status, skills, content, and values in order to advance proposals for improving entrepreneurial skills in Romanian pre-university education.

Objective 6 Determine young people's motivation to start a business between the ages of 16 and 20.

Objective 7 Facilitating the transition from school to the active life of students through the use of methods of entrepreneurship and technological entrepreneurship.

\subsection{Data Description and Objectives Achievement}

This section is based on Questionnaire 1, the student questionnaire on entrepreneurial culture and entrepreneurship in the vocational and technical education (VET) system and was applied online in 2019 using Google Forms with 159 respondents. Also, this section was used for supporting Objectives 4, 5, and 6.

An important question of the survey was focused on information showing the behavioral sides of young people on attitudes and perceptions in the study of entrepreneurship in the Romanian pre-university education, as can be seen in Table 4.

Table 4. Which aspects of behavior regarding attitudes and perceptions, do you think that can be developed in the study of entrepreneurship? (Question 1).

\begin{tabular}{lcc}
\hline \multicolumn{1}{c}{ Variable } & $\begin{array}{c}\text { Absolute Frequencies } \\
\mathbf{( N = \mathbf { 1 5 4 } )} \\
\text { Respondents 1 }\end{array}$ & $\begin{array}{c}\text { Absolute Frequencies } \\
\mathbf{( \% )}\end{array}$ \\
\hline 1.1. It is easy to start a business & 30 & $19 \%$ \\
\hline 1.2. I have entrepreneurial intentions & 53 & $34 \%$ \\
\hline 1.3. I have a skills and knowledge & 42 & $27 \%$ \\
\hline 1.4. I am afraid of failure & 22 & $15 \%$ \\
\hline 1.5. Other & 7 & $5 \%$ \\
\hline
\end{tabular}

Students considered that many perceptions can be developed by studying entrepreneurship in the pre-university education system, so in Table 4 , it can be observed that $34 \%$ of them have entrepreneurial intentions and $27 \%$ of them have acquired skills and knowledge of entrepreneurship. However, $15 \%$ of them felt they had a fear of failure and the other $5 \%$ consider that they have other behavioral sides developed.

Another question about the students' behavior is the motivations and aspirations of young people for entrepreneurship, as can be seen in Table 5 .

Table 5. What are the motivations and aspirations for entrepreneurship during high school (Question 2). 
Students also believe that motivations and aspirations help them to better manage the company $(36 \%)$, but also to start a business in terms of innovation and technology for $23 \%$ of them. However, there are few who would like to take control, so $13 \%$ prefer to continue the family business.

Another question of the study is focused on entrepreneurial activity. Obviously from the previous responses, the results are aimed at the respondent's opinion on entrepreneurship and technology, and the results show that the entrepreneurial idea is a necessity for economic growth. Their role in technology-oriented businesses can be a way to start home-based businesses while maintaining a perfect family-life balance, as can be seen in Table 6.

Table 6. What are the reasons for participating in entrepreneurial activities during high school? (Question 3).

\begin{tabular}{lcc}
\hline \multicolumn{1}{c}{ Variable } & $\begin{array}{c}\text { Absolute Frequencies (N = 154) } \\
\text { Respondents }\end{array}$ & $\begin{array}{c}\text { Absolute Frequencies } \\
\mathbf{( \% )}\end{array}$ \\
\hline 3.1. An entrepreneurial activity as an employee & 56 & $36 \%$ \\
\hline 3.2. An entrepreneurial activity as an employer & 41 & $27 \%$ \\
\hline 3.3. An entrepreneurial activity on technology and innovation & 44 & $29 \%$ \\
\hline 3.4. Other & 13 & $9 \%$ \\
\hline
\end{tabular}

The results gathered show 36\% of respondents said they want entrepreneurial activity as an employee, $27 \%$ want entrepreneurial activity as an employer, and $29 \%$ want an entrepreneurial activity on technology and innovation. However, there are $8 \%$ of them who want something else. Based on the above results, it is recommended that entrepreneurship should become a compulsory discipline and must be taught in all profiles of pre-university education, not only in the service profiles. In other European countries, this is already a common practice, and it should be also adopted in our country. As for the profile of the company that students would like to set up, technology and trade are at the top of the list-options that are in line with market opportunities. Interestingly, 20\% of students choose companies with a profile that can bring innovation to the market, while previously, $74 \%$ of students said they like to work and innovate.

It can be concluded that young people develop a set of social, emotional, cognitive, behavioral, and entrepreneurial skills needed to lead a balanced life. Students will be empowered, which will give them self-confidence. They will be able to think freely and creatively and innovate. Last but not least, they will have the ability to find their own appropriate solutions for the efficient management of the challenges in everyday life.

Table 7 shows that in the Romanian pre-university education system, respondents consider that skills should be improved the most (53\%), then capacity skills (27\%), and finally, knowledge (20\%). The European Commission also stressed that knowledge, skills, and attitudes are essential and must be linked to the competence of an entrepreneurial spirit.

Table 7. Which of the following skills needs to be improved on entrepreneurship in schools? (Question 4).

\begin{tabular}{lcc}
\hline \multicolumn{1}{c}{ Variable } & $\begin{array}{c}\text { Absolute Frequencies }(\mathbf{N}=\mathbf{1 5 4}) \\
\text { Respondents }\end{array}$ & $\begin{array}{c}\text { Absolute Frequencies } \\
\text { (\%) }\end{array}$ \\
\hline 4.1. Knowledge & 31 & $20 \%$ \\
\hline 4.2. Capacity skills & 41 & $27 \%$ \\
\hline 4.3. Skills & 82 & $53 \%$ \\
\hline
\end{tabular}

Individual skills, knowledge, and aspirations greatly influence the success of an entrepreneur. These data show that students are aware of their own qualities that can provide them with a career in entrepreneurship. However, $14 \%$ of students admit that they do not like to work or innovate, associating these qualities with a possible career in 
entrepreneurship. In this case, it can be assumed that these students want other professions in the future.

\subsection{Descriptive Statistics for Testing Hypotheses and Other Objectives Achievement}

This section is based on the second questionnaire, which was the student questionnaire on entrepreneurship education in vocational and technical education units (VET) system and was applied online in 2020 using Google Forms, and we received 254 responses. Also, this section was used for supporting Objectives 1, 2, and 3.

According to Zikmund (2005), the descriptive procedure is useful for obtaining summary comparisons of approximate normally distributed scale variables and for easily identifying unusual cases between those variables. To give a descriptive perspective of the study constructs, a descriptive analysis was performed, and the tables containing the results are shown below in Tables 8-10.

Table 8. Descriptive statistics of individual characteristics.

\begin{tabular}{cccccc}
\hline Variable & N Statistic & $\begin{array}{c}\text { Minimum } \\
\text { Statistic }\end{array}$ & $\begin{array}{c}\text { Maximum } \\
\text { Statistic }\end{array}$ & Mean & $\begin{array}{c}\text { Std. Deviation } \\
\text { Statistic }\end{array}$ \\
\hline Q.1.1 & 254 & 1 & 5 & 4.00 & 1.13 \\
Q.1.2 & 254 & 1 & 5 & 3.59 & 1.24 \\
Q 1.3 & 254 & 1 & 5 & 4.18 & 1.11 \\
Q.1.4 & 254 & 1 & 5 & 4.24 & 1.06 \\
Q.1.5 & 254 & 1 & 5 & 3.87 & 1.20 \\
\hline Valid N & 254 & & & &
\end{tabular}

Mean Average: 3.96. Note: Individual characteristics-Q.1.1-I like to be independent, Q.1.2—I like to be a leader Q.1.3.-I take responsibility for what I do, Q.1.4-I take decisions and risks for what I do, and Q.1.5.-I like to work and innovate.

Table 9. Descriptive statistics of entrepreneurial culture.

\begin{tabular}{cccccc}
\hline Variable & N Statistic & $\begin{array}{c}\text { Minimum } \\
\text { Statistic }\end{array}$ & $\begin{array}{c}\text { Maximum } \\
\text { Statistic }\end{array}$ & Mean & $\begin{array}{c}\text { Std. Deviation } \\
\text { Statistic }\end{array}$ \\
\hline Q.2.1 & 254 & 1 & 5 & 2.70 & 1.35 \\
Q.2.2 & 254 & 1 & 5 & 2.29 & 1.33 \\
Q.2.3 & 254 & 1 & 5 & 2.05 & 1.47 \\
Q.2.4 & 254 & 1 & 5 & 2.92 & 1.43 \\
Q.2.5 & 254 & 1 & 5 & 2.44 & 1.47 \\
\hline Valid N & 254 & & & &
\end{tabular}

Mean Average: 2.48. Note: Entrepreneurial culture-Q.2.1. I have specific skills and competencies in entrepreneurship, Q.2.2. I have participated in courses or workshops on entrepreneurship, Q.2.3. I participated in the courses offered by Junior Achievement., Q.2.4. I followed the Entrepreneurial Education-class X module, and Q.2.5. I participated in entrepreneurial events (fairs, workshops).

Table 8 presents the descriptive statistics indicating that for the five items on individual characteristics perceived among respondents, the average is between 3.87 for the innovation item and 4.24 for the decision-making and risk item. The average for psychological traits is 3.96, which indicates that respondents are moderate in their perception of entrepreneurship. 
Table 10. Descriptive statistics of sources of financing for setting up a company.

\begin{tabular}{cccccc}
\hline Variable & N Statistic & $\begin{array}{c}\text { Minimum } \\
\text { Statistic }\end{array}$ & $\begin{array}{c}\text { Maximum } \\
\text { Statistic }\end{array}$ & Mean & $\begin{array}{c}\text { Std. Deviation } \\
\text { Statistic }\end{array}$ \\
\hline Q.3.1 & 254 & 1 & 5 & 2.08 & 1.42 \\
Q.3.2 & 254 & 1 & 5 & 2.16 & 1.48 \\
Q.3.3 & 254 & 1 & 5 & 2.05 & 1.40 \\
Q.3.4 & 254 & 1 & 5 & 2.16 & 1.43 \\
Q.3.5 & 254 & 1 & 5 & 1.94 & 1.31 \\
\hline Valid N & 254 & & & &
\end{tabular}

Mean Average: 2.08. Note: Sources of financing-Q.3.1 Accessing the Start-Up program, Q.3.2. Access to other European funds, Q.3.3. Financial leasing, Q.3.4. Bank credit, and Q.3.5. Business incubators.

In Table 9, the authors analyzed the average for the five elements that constitute the entrepreneurial culture and found this indicator between 2.05 for extra-curricular entrepreneurial education and 2.72 for entrepreneurial activity skills and abilities. The average of the 5 items is 2.48 , which indicates that respondents are moderate about the entrepreneurial culture.

Table 10 presents the average score for items of funding (2.08), which shows that these respondents are moderate in terms of sources of funding for a new firm in the market. Since the average is between 1.94 for business incubators and 2.16 for Start-Up programs for accessing European funds, these very small averages indicate that respondents do not have enough information to attract funds for a future company.

In Table 11, the authors analyzed a correlation between independent variables with the dependent variable on psychological traits, entrepreneurial culture, and funding sources.

Table 11. Correlation matrix of major variables.

\begin{tabular}{ccccccccc}
\hline Variable & Indicator & Q1.1 & Q1.5 & Q2.1 & Q2.2 & Q2.4 & Q3.1 & Q3.4 \\
\hline IC & Q.1.1 & 1 & & & & & & \\
N = 254 & Q.1.5 & 0.962 & 1 & & & & & \\
EC & Q.2.1 & 0.792 & 0.804 & 1 & & & & \\
N = 254 & Q.2.2 & 0.731 & 0.732 & 0.922 & 1 & & \\
& Q.2.4 & 0.846 & 0.860 & 0.931 & 0.918 & 1 & & \\
SF & Q.3.1 & 0.651 & 0.664 & 0.868 & 0.943 & 0.861 & 1 & \\
N = 254 & Q.3.4. & 0.674 & 0.692 & 0.879 & 0.944 & 0.870 & 0.876 & 1
\end{tabular}

Correlation is significant at the 0.01 level (2-tailed). Note: IC-Individual characteristics, EC-entrepreneurial culture, and SF-Sources of financing.

Pearson product-moment correlation analysis was used to determine the nature, direct or inverse, and the degree of association between variables, while multiple regions were used to determine the explanatory power of independent variables over the dependent variable. This is a common measure of the relationships between numerical variables measured on the Likert scale. The correlation matrix shows the strength of the association between the variables and is presented above in Table 11. The table above shows the cross-correlation coefficients of the main constructs in this study. As the table indicates, the entrepreneurial intention is significantly and positively related to adequate perception with the correlation coefficient $(p<0.01)$. Therefore, the authors conclude that there is a strong, significant, and positive association between these two constructions.

\subsection{Statistical Analyzes and Study Results}

The authors' further attempt was to validate the two hypotheses proposed at the beginning of the study by using the statistical techniques provided by SPSS as well as from the above graphical analysis where the authors have interpreted the questionnaires applied in 2019-2020. The purpose of analyzing data and testing the hypotheses was aimed at establishing the approximation or distance of the distribution of the values from the 
Gaussian distribution by using histograms and the deviations generated by asymmetry (Skewness) and vaulting (Kurtosis).

To demonstrate Hypothesis H1, the authors started by quantifying the degree of implementation of variables (attitudes and perceptions, motivations and aspirations, entrepreneurial activity) from the questionnaires applied. Analyzing the independent variable with the dependent variable by calculating its variable correlation matrix, the authors have observed that there is a positive relationship between independent variables and the dependent variable, which explains that an increase in an independent variable has an increasing effect on the other.

The link between variables is highlighted in Table 12 by the multiple correlation coefficient obtained in this analysis $(R=0.969)$ - a value that shows a very good link between the dependent variable and the independent variables. The model is valid because $\mathrm{F}$ has a high level of significance and indicates a very significant relationship between the established variables. The model explains $96 \%$ of the total variation of the dependent variable ( $R 2=0.938)$, and the remaining $4 \%$ is influenced by other factors. Data on the linear multiple regression analysis is required to test Hypothesis $\mathrm{H} 1$, and it can be observed that $\mathrm{R}^{2}$ has adequate values on students' intentions to engage in future entrepreneurial efforts. In other words, the intention for future entrepreneurial activities can be promoted by the dissemination of information that will encourage students to combine their attitude with a career in entrepreneurship and an acceptable and appropriate career after graduation. Based on the results obtained from statistical analyses, the authors conclude that the Hypothesis H1 is accepted, and it is a correlation between the pre-university entrepreneurial leading and positively influences the variables (attitudes and perceptions, motivations and aspirations, entrepreneurial activity) regarding the entrepreneurial intention of the students.

Table 12. Multiple regression analysis between the independent variables and the dependent variable on entrepreneurial intentions.

\begin{tabular}{|c|c|c|c|c|c|c|c|c|c|}
\hline \multicolumn{10}{|c|}{ Model Summary } \\
\hline \multirow[t]{2}{*}{ Model } & $\mathbf{R}$ & R Square & Adjusted & Std. Error of & \multicolumn{5}{|c|}{ Change Statistics } \\
\hline & & & & & $\begin{array}{l}\text { R Square } \\
\text { Change }\end{array}$ & F Change & df1 & df2 & $\begin{array}{l}\text { It's getting you out } \\
\text { of here F Change }\end{array}$ \\
\hline \multirow[t]{3}{*}{1} & $0.969^{a}$ & 0.939 & 0.935 & 0.121 & 0.939 & 220.231 & 10 & 143 & $<0.001$ \\
\hline & \multicolumn{9}{|c|}{ ANOVA $^{b}$} \\
\hline & \multicolumn{2}{|l|}{ Model } & $\begin{array}{l}\text { Sum of } \\
\text { Squares }\end{array}$ & $\mathrm{df}$ & $\begin{array}{l}\text { Mean } \\
\text { Square }\end{array}$ & $\mathrm{F}$ & \multicolumn{3}{|c|}{ It's getting you out of here } \\
\hline \multirow{3}{*}{1} & \multicolumn{2}{|c|}{ Regression } & 32.342 & 10 & 3.234 & 220.231 & \multicolumn{3}{|c|}{$<0.001^{\mathrm{c}}$} \\
\hline & \multicolumn{2}{|c|}{ Residual } & 2.100 & 143 & 0.015 & & & & \\
\hline & \multicolumn{2}{|c|}{ Total } & 34.442 & 153 & & & & & \\
\hline
\end{tabular}

a Predictors: (Constant) An entrepreneurial activity on technology and innovation. I would continue my family business. An entrepreneurial activity as an employee, I would like to earn a living, fear of failure, an entrepreneurial activity as an employer, starting a company, I would like to start a business in the field of technology, I would like to start a business, skills, and knowledge. ${ }^{\mathrm{b}}$ Dependent Variable: Entrepreneurial intentions. ${ }^{c}$ Predictors: (Constant) An entrepreneurial activity on technology and innovation. I would continue my family business. An entrepreneurial activity as an employee, I would like to earn a living, fear of failure, an entrepreneurial activity as an employer, starting a company, I would like to start a business in the field of technology, I would like to start a business, skills, and knowledge.

To demonstrate Hypothesis $\mathrm{H} 2$, the authors started by quantifying the degree of implementation of high school entrepreneurial education accumulated during the 4 years. In the questionnaires applied on the exercise firm and implicitly entrepreneurial education, the authors found what field students want to set up their own company. From the correlation matrix analyzed, the authors have observed that there is a positive relationship between independent variables and the dependent variable, which explains that an increase in an independent variable has an increasing effect on the other.

The link between variables is highlighted in Table 13 by the multiple correlation coefficient obtained in this analysis $(R=0.982)$-a value that shows a very good link 
between the dependent variable and the independent variables. The model is valid because $\mathrm{F}$ has a high level of significance and indicates a very significant relationship between the established variables. The model explains $98 \%$ of the total variation of the dependent variable $(\mathrm{R} 2=0.965)$, and the remaining $2 \%$ is influenced by other factors.

Table 13. Multiple regression analysis between independent variables and the dependent variable on the exercise firm for 159 respondents.

\begin{tabular}{|c|c|c|c|c|c|c|c|c|c|}
\hline \multicolumn{10}{|c|}{ Model Summary } \\
\hline \multirow[t]{2}{*}{ Model } & \multirow[t]{2}{*}{$\mathbf{R}$} & \multirow[t]{2}{*}{ R Square } & \multicolumn{2}{|c|}{ Adjusted R Square } & \multirow{2}{*}{$\begin{array}{l}\text { Std. Error of } \\
\text { the Estimate }\end{array}$} & \multicolumn{4}{|c|}{ Change Statistics } \\
\hline & & & & & & F Change & df1 & df2 & $\begin{array}{l}\text { It's getting you out } \\
\text { of here F Change }\end{array}$ \\
\hline \multirow[t]{3}{*}{1} & $0.982^{\mathrm{a}}$ & 0.965 & & & 0.250 & 1405.150 & 3 & 155 & $<0.001$ \\
\hline & \multicolumn{9}{|c|}{ ANOVA $^{b}$} \\
\hline & \multicolumn{2}{|c|}{ Model } & $\begin{array}{l}\text { Sum of } \\
\text { Squares }\end{array}$ & df & Mean Square & $\mathrm{F}$ & \multicolumn{3}{|c|}{ It's getting you out of here } \\
\hline \multirow{3}{*}{1} & \multicolumn{2}{|c|}{ Regression } & 263.409 & 3 & 87.803 & 1405.150 & \multicolumn{3}{|c|}{$<0.001^{\mathrm{c}}$} \\
\hline & \multicolumn{2}{|c|}{ Residual } & 9.685 & 155 & 0.062 & & & & \\
\hline & \multicolumn{2}{|c|}{ Total } & 273.094 & 158 & & & & & \\
\hline
\end{tabular}

a Predictors: (Constant) The exercise company helped you develop your personal skills to be a future entrepreneur, the exercise company helped you develop your entrepreneurial behavior, and the exercise company helped you develop to be an entrepreneur. ${ }^{\mathrm{b}}$ Dependent Variable: The exercise company helped you develop your intention to be a future entrepreneur. ${ }^{c}$ Predictors: (Constant) The exercise company helped you to develop your personal skills to be a future entrepreneur, the exercise company helped you to develop an entrepreneurial behavior, and the exercise company helped you to develop to be an entrepreneur.

The analyses made over the entrepreneurial intentions show a strong link between variables that is highlighted in Table 14 by the multiple correlation coefficient obtained in this analysis $(R=0.969)$ - a value that shows a very good link between the dependent variable and the independent variables. The model is valid because $\mathrm{F}$ has a high level of significance and indicates a very significant relationship between the established variables. The model explains $96 \%$ of the total variation of the dependent variable $\left(R^{2}=0.939\right)$, and the remaining $4 \%$ is influenced by other factors.

Table 14. Multiple regression analysis between the independent variables and the dependent variable on entrepreneurial intentions for 254 respondents.

\begin{tabular}{ccccccccc}
\hline \multicolumn{1}{c}{ Model Summary } & & & \\
\hline Model & R & R Square & $\begin{array}{c}\text { Adjusted } \\
\text { R Square }\end{array}$ & $\begin{array}{l}\text { Std. Error of } \\
\text { the Estimate }\end{array}$ & & Change Statistics \\
\hline & & & & F Change & df1 & $\begin{array}{c}\text { It's getting you out } \\
\text { of here F Change }\end{array}$ \\
\hline 1 & $0.969^{\text {a }}$ & 0.939 & 0.935 & 0.121 & 220.231 & 3 & 254 \\
\hline
\end{tabular}

a Predictors: (Constant) Entrepreneurial activity in the exercise company helped you develop entrepreneurial behavior, the exercise company helped you develop your personal skills to be a future entrepreneur. ${ }^{\mathrm{b}}$ Predictors: (Constant) Entrepreneurial activity in the exercise company helped you develop entrepreneurial behavior, the exercise company helped you develop your personal skills to be a future entrepreneur.

In conclusion, the model achieved a good precision of entrepreneurial intent among the students in this study. Finally, from the analysis of the data and the interpretation of the above data, they indicate a significant relationship between the independent variable and the dependent variable on the other side. This validates Hypothesis $\mathrm{H} 2$, where the entrepreneurial activity in the exercise firm positively influences them to become future entrepreneurs since they already have contact with a virtual firm in which all the activities of a firm are simulated. 
The link between the variables is highlighted in Table 15 by the multiple correlation coefficient obtained in this analysis $(R=0.949)$ - a value that shows a very good link between the dependent variable and the independent variables. The model is valid because $\mathrm{F}$ has a high level of significance and indicates a very significant relationship between the established variables.

Table 15. Multiple regression analysis between the independent variables and the dependent variable.

\begin{tabular}{|c|c|c|c|c|c|c|c|c|}
\hline \multicolumn{9}{|c|}{ Model Summary } \\
\hline \multirow[t]{2}{*}{ Model } & \multirow[t]{2}{*}{$\mathbf{R}$} & \multirow[t]{2}{*}{ R Square } & \multirow[t]{2}{*}{$\begin{array}{l}\text { Adjusted } \\
\text { R Square }\end{array}$} & \multirow[t]{2}{*}{$\begin{array}{l}\text { Std. Error of } \\
\text { the Estimate }\end{array}$} & \multicolumn{4}{|c|}{ Change Statistics } \\
\hline & & & & & F Change & df1 & df2 & $\begin{array}{l}\text { It's getting you out } \\
\text { of here F Change }\end{array}$ \\
\hline 1 & $0.974^{\mathrm{a}}$ & 0.948 & 0.947 & 0.278 & 644.525 & 7 & 246 & $<0.001$ \\
\hline 1 & $0.949^{b}$ & 0.900 & 0.897 & 0.43534 & 369.654 & 6 & 247 & $<0.001$ \\
\hline
\end{tabular}

The model explains $94 \%$ of the total variation of the dependent variable $(\mathrm{R} 2=0.900)$, and the remaining $6 \%$ is influenced by factors. The data on the linear multiple regression analysis is needed to test the hypothesis in this thesis, and it can be seen that R2 has adequate values regarding students' intentions to engage in future entrepreneurial efforts.

The model is valid because $F$ has a high level of significance and indicates a very significant relationship between the established variables.

The model explains $97 \%$ of the total variation of the dependent variable $(R 2=0.948)$, and the remaining $3 \%$ is influenced by other factors. The data on the linear multiple regression analysis is needed to test the hypothesis in this thesis, and it can be seen that $\mathrm{R} 2$ has adequate values regarding the intentions of students to engage in future entrepreneurial efforts.

After analyzing the above data and statistics, the author showed that Hypothesis H3, which says that students/young people are influenced by the variables (individual characteristics, entrepreneurial culture, funding sources) in the decision to start a business, is accepted because there are stable relationships between dependent variables and independent variables.

At the end of this section, the authors conclude that objectives 6 and 7 are supported, and also the three proposed hypotheses have been demonstrated and accepted.

\section{Discussion}

Entrepreneurship is important for job creation, economic growth, and innovation. It can also strengthen social inclusion and address societal challenges through policies of entrepreneurship, social entrepreneurship, and technological entrepreneurship. Innovation and entrepreneurship are in an interdependent relationship. Innovation can be considered a resource available to any entrepreneur, providing him with valuable tools for integration into the competitive business environment, adaptation and, of course, growth and development in a competitive business environment. Entrepreneurship supports innovation, as demonstrated by the policies of the European Union and taken over by the entrepreneurial policies in Romania. This study highlights that the new generations of Romanian entrepreneurs with unlimited access to information will change Romania's status as a "modest innovator," as mentioned in the European Innovation Scoreboard.

Economic growth is strongly correlated with the abundance of small, entrepreneurial firms; this relationship shows technological progress, stimulates product cycles, where growth is faster in the previous stages, and the importance of entrepreneurship. Instead, the evidence suggests that spatial differences in the fixed costs of entrepreneurship in the offer of entrepreneurs best explain the formation of clusters. Group learning experiences within an exercise firm are marked by the stimulation of critical thinking and the self-confidence 
that students gain during the implementation of this experimental learning strategy. It also contributes to the establishment of a relaxed working relationship between the educator and the educated. If at first students found it harder to organize, they got used to working in this way, and some of them are showing creativity. Creativity is an essential prerequisite for innovation, which is necessary for Romanian entrepreneurial organizations to become competitive in the European market. Vocational and technical education (VET) in Romania tries to train young students in entrepreneurial skills, skills, and attitudes by training and practicing them in a modern, flexible, and connected learning framework to the demands of the global business environment. From this perspective, an entrepreneurial innovation is being attempted, i.e., a transfer of technological entrepreneurship that is structured and most importantly sustainable.

The current results of the various studies show that entrepreneurship education encourages young people to start their own business and more, has a positive impact on the students' self-assessment and attitude towards entrepreneurship, as well as their aspirations and achievements. There have also been studies such as that of Rita R, Grazina $\mathrm{S}$, and Daiva D, which have studied the factors that influence entrepreneurial intent, concluding that entrepreneurial intent is mostly influenced by personal factors, personality traits, which can be developed by following studies on entrepreneurship. Therefore, personality traits have been shown to have a direct impact on entrepreneurial intent, but this impact can become even more strengthened through entrepreneurial education [79].

Compared to other research made worldwide (28), especially in Romania (13) during the last 3 or 4 years, the authors tried to demonstrate that entrepreneurship education in high schools can influence the entrepreneurial intentions of the students and then the Romanian business market development.

In Romania, at the level of technological high schools, entrepreneurship should not be promoted and supported as an alternative for a professional career but should also be integrated into an ecosystem of entrepreneurial education at secondary, high school, and university level. Further, a national strategy with other European countries for a successful model could be developed. Internationally, entrepreneurship is a key element for job creation and the economic growth of a country. Supporting entrepreneurship has come to be a key priority and a solution to relaunch the economy. It follows from this research that young people certainly have concerns to develop businesses, a huge motivation to start their own projects. and a good perspective on entrepreneurial activities that are effective tools to increase their incomes. Their motivation is high, and they are also impressed by the newly arrived IT giants, considering that technology companies offer an economic boost both as an employer and as an employee.

A student's practice and activity in entrepreneurial activity in the practice firm should be considered professional experience for the student, and this is the opportunity to learn and obtain more skills and to identify which career or specialization best suits him or her socio-professional profile. In recent years, Romanian pre-university education tends to develop and capitalize on the integration of experimental learning strategies such as exercise firms, thus stimulating their idea of launching a commercial or social project. There are also situations where some students do not want to be actively involved in the work of exercise firms because they argue that they do not want to own their own business, and in this case, the teacher must shape the mentality of young people regarding entrepreneurship education: it is not only those who will launch their own business who have to work in an exercise firm. Entrepreneurial education forms and stimulates the entrepreneurial spirit required of any employee in a firm or institution, which depends very much, after all, on the efficient functioning of an institution or the development of the business.

In 2020, the EU education ministers met in Osnabrück to achieve a new strategy for VET education and achieve cross-border cooperation within the European Education Area, according to the Osnabrück Declaration (2020). The European strategy for 2020-2027 is built around three pillars: monitoring developments and assessing countries in need of modernizing education and training systems, providing policy advice to partner coun- 
tries and EU institutions, and achieving a global knowledge hub for people and capital development in developing and transition countries [80].

In line with the identified trends and challenges, a greater focus should involve a change in workplace learning that offers specific key technical and entrepreneurial skills so as to facilitate the transition in the labor market. Learning and career development should also be improved by achieving learning paths with good integration and coordination between general education, as well as between formal, non-formal, and informal training, as well as for lifelong learning. Based on these and taking into account the Global Entrepreneurship Monitor reports [81], it is recommended that school authorities and relevant stakeholders engage in mass communication in the dissemination of information that favors perceived adequacy and perceived effectiveness, in addition to improving the quality of entrepreneurial training facilities in schools.

Romania has been part of the EU since 2007, and in the field of entrepreneurship, it is not far behind other states, especially in businesses developed by young entrepreneurs. The central region could be considered representative of the Romanian field of technological entrepreneurship because the industrial specificity is pronounced in the counties of Brasov and Sibiu - counties with important industrial traditions. The authors based this study on the fact that the central region of Romania is the Romanian region that has developed the most start-up businesses based on entrepreneurship schemes financed by the Romanian government and EU, which demonstrates the entrepreneurship potential of the region.

\section{Conclusions}

In conclusion, the authors have revealed that supporting entrepreneurship has become a key priority and a solution to revive the economy. This research shows that young people certainly have concerns about developing business, a huge motivation to start their own projects, and a good perspective on entrepreneurial enterprises that are effective tools to increase their income. Their motivation is high, and they are also impressed by the recent IT giants, considering that technology companies offer an economic boost either from the position of employer versus employee.

The study revealed that the students were determined to work successfully in the exercise company and in entrepreneurial activities, and they worked with pleasure. The very good results did not take long to appear, and the training within the exercise company proved to be interdisciplinary, oriented towards an experimental strategy (action and problems), focused on students, and inspired by practice.

The process of creating technological entrepreneurship is largely conditional on the trainers' expertise and their ability to identify, study, and stimulate students in different contexts, case studies, tools, and learning activities that are adapted to the economic and social context in which we are located.

Another conclusion was that basing a business on technology, in fact, entrepreneurship based on computer-assisted systems and methodologies, can not only bring innovation but also guarantees more profitability, in contrast to fewer investments that would otherwise have been needed in traditional enterprises of the same level. So, it is time for investors to bring the small- and medium-sized business sector into perfect alignment with technologybased businesses. As loans are important for financing start-ups, it is mandatory for banks to make policies and procedures to enable potential businesses to comply with financing options. A student's practice and activity in entrepreneurial activity in the practice firm should be considered professional experience for the student, and this is the opportunity to learn and obtain more skills and to identify which career or specialization best suits him or her socio-professional profile. In recent years, the Romanian pre-university education tends to develop and capitalize on the integration of experimental learning strategies such as exercise firms, thus stimulating their idea of launching a commercial or social project. There are also situations where some students do not want to be actively involved in the work of exercise firms because they argue that they do not want to own their own business. In this case, the teacher must shape the mentality of young people regarding entrepreneurship 
education: it is not only those who will launch their own business who have to work in an exercise firm. Entrepreneurial education forms and stimulates the entrepreneurial spirit required of any employee in a firm or institution, which depends very much, after all, on the efficient functioning of an institution or the development of the business. In line with the identified trends and challenges, a greater focus should involve a change in the workplace learning offers specific to key technical skills and entrepreneurial skills so as to facilitate the transition in the labor market. Learning and career development should also be improved by achieving learning paths with good integration and coordination between general education, as well as between formal, non-formal and informal training, as well as for lifelong learning. Based on these, it is recommended that school authorities and relevant stakeholders engage in mass communication about the dissemination of information that favors perceived adequacy and perceived effectiveness, in addition to improving the quality of entrepreneurial training facilities in schools.

The study shows that there is a very high trend for the establishment of innovationbased businesses to cope with worsening economic scenarios, especially when there is a high interest and motivation among young people to start innovation-based businesses, technology because they represent the future of any country.

\section{Policy Implications and Study Limitations}

Regarding the limitations of this study, even though it reveals the points of view of a representative population of students and professors from the Romanian primary and secondary education system, the results are limited in terms of their level of generalizability because of cultural contexts and participants' particularities from the central region. Another limitation is related to the item construction that measured the level of entrepreneur culture implementation, but also the future research design could be improved. Self-reporting and self-evaluation can also be risk factors because of social desirability.

In the field of policy implications of this study results, the authors believe that we can expect greater awareness of the need to develop and establish models of progress for entrepreneurship and technology entrepreneurship, rather than continuing to seek an approach to entrepreneurship education. We can also hope for researchers to identify characteristics of entrepreneurship education at all levels of education to a higher degree of certainty and with stronger empirical evidence than was possible. Also, the authors hope in the future that teachers will have access to qualifications and other support materials that allow them to choose from a wide variety of pedagogical tools and methods, enabling them to quickly identify and improve a teaching style and a progress strategy appropriate to their own students, and for the beginning, it must be created a built-in value for all students.

Based on this study, their educational experience in business, and over 20 years of entrepreneurial experience, the authors conclude that it is necessary to expect a better understanding and learning through achievement in the future. This can be integrated into education at all levels and for most subjects in the curricular area. Tools, methods, and concepts must be contextualized through education, leading to useful materials to support teachers and students for tasks performed through close collaboration between experienced teachers and dedicated to all levels of education and researchers in entrepreneurship and education.

Author Contributions: A.F. carried out the research based on his own questionnaires on online entrepreneurship through the partnership agreements concluded with the technological high schools of the Central Region of Romania. E.E. and L.L.-D. established the theoretical background and carried out the analysis of the Romanian entrepreneurship education system. All authors have read and agreed to the published version of the manuscript.

Funding: This research received no external funding.

Institutional Review Board Statement: The study was conducted according to the guidelines of the Declaration of Helsinki.

Informed Consent Statement: Informed consent was obtained from all subjects involved in the study. 
Data Availability Statement: The data presented in this study are available on request from the first author.

Conflicts of Interest: The authors declare no conflict of interest.

\section{References}

1. Brancu, L.; Munteanu, V.; Gligor, D. Study on Student's Motivations for Entrepreneurship in Romania. Proc. Soc. Behav. Sci. 2012, 62, 223-231. [CrossRef]

2. Zamfir, A.-M.; Lungu, E.-O.; Mocanu, C. Study of Entrepreneurship Behavior among Higher Education Graduates in 13 European Countries. Theor. Appl. Econ. 2013, 18, 588.

3. Dodescu, A.O.; Botezat, E.A.; Cohut, I.C.P.; Borma, A. Antecedents, Experiences and Entrepreneurial Intentions among Economics Students. In Proceedings of the 12th LUMEN International Scientific Conference Rethinking Social Action. Core Values in Practice RSACVP 2019, Asociatia LUMEN, Iasi, Romania, 15-17 May 2019.

4. Chigunda, F.; Schnurr, J.; Hames-Wilson, D. Youth Entrepreneurship: Meeting the Key Policy Challenges; Wolson College, Oxford University: Oxford, UK, 2002.

5. Dodescu, A.O.; Cohut, I.C.P. Youth Entrepreneurship and Role Models at Local Level. Case Study: Bihor County, Romania. Rethink. Soc. Action Core Val. Prac. 2018, 5, 117-134. [CrossRef]

6. Schoof, U. Stimulating Youth Entrepreneurship: Barriers and Incentives to Enterprise Start-Ups by Young People; International Labour Office: Geneva, Switzerland, 2006.

7. Kuratko, D.F.; Ireland, R.D.; Covin, J.G.; Hornsby, J.S. A model of middle level managers' entrepreneurial behavior. Entrepreneur. Theory Pract. 2005, 29, 699-716. [CrossRef]

8. Kuratko, D.F.; Hodgetts, R.M. Entrepreneurship: Theory, Process; Practice; South-Western College Publishers: Mason, OH, USA, 2004.

9. Ratten, V. Sport-based entrepreneurship: Towards a new theory of entrepreneurship and sport management. Int. Entrep. Manag. J. 2011, 7, 57-69. [CrossRef]

10. Fernandez-Guadaño, J.; Lopez-Millan, M.; Sarria-Pedroza, J. Cooperative Entrepreneurship Model for Sustainable Development. Sustainability 2020, 12, 5462. [CrossRef]

11. Busu, C.; Busu, M. Modeling the Circular Economy Processes at the EU Level Using an Evaluation Algorithm Based on Shannon Entropy. Process. 2018, 6, 225. [CrossRef]

12. Briciu, A.; Briciu, V.-A.; Kavoura, A. Evaluating How 'Smart' Brașov, Romania Can Be Virtually via a Mobile Application for Cultural Tourism. Sustainability 2020, 12, 5324. [CrossRef]

13. Bican, P.M.; Brem, A. Digital Business Model, Digital Transformation, Digital Entrepreneurship: Is There A Sustainable "Digital”? Sustainability 2020, 12, 5239. [CrossRef]

14. Schepers, J.; Voordeckers, W.; Steijvers, T.; Laveren, E. Long-Term Orientation as a Resource for Entrepreneurial Orientation in Private Family Firms: The Need for Participative Decision Making. Sustainability 2020, 12, 5334. [CrossRef]

15. Yamaguchi, C.K.; Stefenon, S.F.; Ramos, N.K.; Dos Santos, V.S.; Forbici, F.; Klaar, A.C.R.; Ferreira, F.C.S.; Cassol, A.; Marietto, M.L.; Yamaguchi, S.K.F.; et al. Young People's Perceptions about the Difficulties of Entrepreneurship and Developing Rural Properties in Family Agriculture. Sustainability 2020, 12, 8783. [CrossRef]

16. Carriles-Alberdi, M.; Lopez-Gutierrez, C.; Fernandez-Laviada, A. The Influence of the Ecosystem on the Motivation of Social Entrepreneurs. Sustainability 2021, 13, 922. [CrossRef]

17. Global Entrepreneurship Monitor, 2016/17. Available online: https://www.gemconsortium.org/report/gem-2016-2017-globalreport (accessed on 17 January 2021).

18. Kim, M.; Lee, J.-H.; Roh, T.; Son, H. Social Entrepreneurship Education as an Innovation Hub for Building an Entrepreneurial Ecosystem: The Case of the KAIST Social Entrepreneurship MBA Program. Sustainability 2020, 12, 9736. [CrossRef]

19. Isenberg, D. The Entrepreneurship Ecosystem Strategy as a New Paradigm for Economic Policy: Principles for Cultivating Entrepreneurship; Babson Entrepreneurship Ecosystem Project; Babson College: Babson Park, MA, USA, 2011.

20. Entrepreneurial Ecosystem Diagnostic Toolkit. Aspen Network of Development Entrepreneurs. 2013. Available online: https:/ / www.aspeninstitute.org/wpcontent/uploads/files/content/docs/pubs/FINAL\%2N0Ecosystem\%20Toolkit\%20 Draft_print\%20version.pdf (accessed on 10 January 2021).

21. Isenberg, D. Introducing the Entrepreneurship Ecosystem: Four Defining Characteristics. Available online: https://www.forbes. $\mathrm{com} /$ sites / danisenberg/2011/05/25/introducing-the-entrepreneurship-ecosystem-four-definingcharacteristics / ?sh=5bd1 ada65fe8N (accessed on 12 January 2021).

22. Brătucu, G.; Lixăndroiu, R.C.; Constantin, C.P.; Tecău, A.S.; Chițu, I.B.; Trifan, A. Entrepreneurial University: Catalyst for Regional Sustainable Development. Sustainability 2020, 12, 4151. [CrossRef]

23. Andrez, P.; Ttaj, D.; Dalle, J.-M.; Romanainen, J. Specific Support Startups, Scaleups and Entrepreneurship in Romania, Horizon 2020 Policy Support Facility. (Finland, Expert. TWO: 10.2777/68810). Available online: https://rio.jrc.ec.europa.eu/library/ specific-support-romania-final-report-start-ups-scale-ups-and-entrepreneurship-romania (accessed on 28 January 2021).

24. Bărbulescu, O.; Tecău, A.; Munteanu, D.; Constantin, C. Innovation of Startups, the Key to Unlocking Post-Crisis Sustainable Growth in Romanian Entrepreneurial Ecosystem. Sustainability 2021, 13, 671. [CrossRef]

25. Lewis, K.; Massey, C. Youth Entrepreneurship and Government Policy; New Zealand Centre for SME Research, Massey University: Palmerstone North, New Zealand, 2003. 
26. Gibb, A.A. Stimulating New Business Development, What else besides EDP. In Stimulating Entrepreneurship and New Business Development, Chapter 3; ILO: Geneva, Switzerland, 1988.

27. OECD. Putting The Young in Business: Policy Challenges for Youth N Entrepreneurship; The LEED Programme, Territorial Development Division: Paris, France, 2001.

28. Henry, C.; Hill, F.; Leitch, C. Entrepreneurship education and training: Can entrepreneurship be taught? Part I. Educ. Train. 2005, 47, 98-111. [CrossRef]

29. Oncioiu, I.; Căpuşneanu, S.; Constantin, D.-M.O.; Türkeș, M.C.; Topor, D.I.; Bîlcan, F.R.; Petrescu, A.G. Improving the Performance of Entities in the Mining Industry by Optimizing Green Business Processes and Emission Inventories. Processes 2019, 7, 543. [CrossRef]

30. Cárcel-Carrasco, J.; Gómez-Gómez, C. Qualitative Analysis of the Perception of Company Managers in Knowledge Management in the Maintenance Activity in the Era of Industry 4.0. Processes 2021, 9, 121. [CrossRef]

31. Ellis, K.; Williams, C. Maximising Impact of Youth Entrepreneurship Support in Different Contexts, Back-Ground Report, Framework and Toolkit for Consultation; Overseas Development Institute: London, UK, 2011.

32. García, A.I.; Álvarez, T.G.; Román, M.G.; Martín, V.G.; Merchán, D.T.; Zamudio, S.C. University Mentoring Programmes for Gifted High School Students: Satisfaction of Workshops. Sustainability 2020, 12, 5282. [CrossRef]

33. Parker, S.C. The Economics of Self-Employment and Entrepreneurship; Cambridge University Press (CUP): Cambridge, UK, 2004.

34. Cuervo, Á.; Ribeiro, D.; Roig, S. Entrepreneurship: Concepts, Theory and Perspective. Introduction. In Entrepreneurship; Cuervo, Á., Ribeiro, D., Roig, S., Eds.; Springer: Berlin/Heidelberg, Germany, 2007. [CrossRef]

35. Schumpeter, J. The Theory of Economic Development: An Inquiry into Profits, Capital, Credit, Interest, and the Business Cycle; Harvard University Press: Cambridge, UK, 1983.

36. Francis, D.H.; Banning, K. Who Wants to be an Entrepreneur? J. Acad. Bus. Educ. 2001, 1, 5-11.

37. Korunka, C.; Frank, H.; Lueger, M.; Mugler, J. The Entrepreneurial Personality in the Context of Resources, Environment, and the Startup Process-A Configurational Approach. Entrep. Theory Pr. 2003, 28, 23-42. [CrossRef]

38. Adekiya, A.A.; Ibrahim, F. Entrepreneurship intention among students. The antecedent role of culture and entrepre-neurship training and development. Int. J. Manag. Educ. 2016, 14, 116-132. [CrossRef]

39. García-Jurado, A.; Pérez-Barea, J.; Nova, R. A New Approach to Social Entrepreneurship: A Systematic Review and Meta-Analysis. Sustainability 2021, 13, 2754. [CrossRef]

40. Shapero, A.; Sokol, L. The Social Dimensions of Entrepreneurship; Urbana-Champaign's Academy for Entrepreneurial Leadership Historical Research Reference in Entrepreneurship: Champaign, IL, USA, 1982.

41. CEE (Consortium for Entrepreneurship Education). Entrepreneurship Education Everywhere. 2005. Available online: http: //www.entre-ed.org/_entre/whitepaperfinal.pdf (accessed on 17 January 2021).

42. Drucker, P.F. Innovation and Entrepreneurship; Harper Collins Publishers: New York, NY, USA, 1993.

43. Lu, G.; Song, Y.; Pan, B. How University Entrepreneurship Support Affects College Students' Entrepreneurial Intentions: An Empirical Analysis from China. Sustainability 2021, 13, 3224. [CrossRef]

44. Butum, L.C.; Nicolescu, L.; Stan, S.O.; Găitănaru, A. Providing Sustainable Knowledge for the Young Graduates of Economic and Social Sciences. Case Study: Comparative Analysis of Required Global Competences in Two Romanian Universities. Sustainability 2020, 12, 5364. [CrossRef]

45. Cioca, L.-I.; Bratu, M. Sustainability of Youth Careers in Romania-Study on the Correlation of Students' Personal Interests with the Selected University Field of Study. Sustainability 2020, 13, 229. [CrossRef]

46. Frolova, Y.; Alwaely, S.; Nikishina, O. Knowledge Management in Entrepreneurship Education as the Basis for Creative Business Development. Sustainability 2021, 13, 1167. [CrossRef]

47. Yuan, C.-H.; Wang, D.; Mao, C.; Wu, F. An Empirical Comparison of Graduate Entrepreneurs and Graduate Employees Based on Graduate Entrepreneurship Education and Career Development. Sustainability 2020, 12, 10563. [CrossRef]

48. Edelhauser, E.; Ionică, A. A Business Intelligence Software Made in Romania, a Solution for Romanian Companies During the Economic Crisis, Computer Science and Information Systems; Journal ComSIS: Novi Sad, Serbia, 2014; Volume 11, pp. 809-823. Available online: http:/ / www.comsis.org/archive.php?show=pprms-1304 (accessed on 20 January 2021). [CrossRef]

49. Hatos, A.; Hatos, R.; Bădulescu, A.; Bădulescu, D. Are Risk Attitudes and Individualism Predictors of Entrepreneurship in Romania? Amfiteatru Economic 2015, 17, 148-161.

50. Xavier, S.R.; Kelley, D.; Herrington, M.; Vorderwulbecke, A. Global Entrepreneurship Monitor (GEM) 2012 Global Report. 2013. Available online: https:/ / www.gemconsortium.org/report/gem-2012-global-report (accessed on 17 January 2021).

51. Lupu-Dima, L.; Edelhauser, E.; Corbu, E.C.; Furdui, A. Innovative Method of Increasing the Quality of Management in Administration Using the Principles of Sharing Economy. Qual. Access Success 2019, 20 (Suppl. 1), 507-512, ISSN $1582-2559$.

52. Csaba, C.; Badulescu, A.; Cadar, O. Economic and Entrepreneurial Education in Romania in the European context. WLC 2016 World LUMEN Congress. Logos Univers. Ment. Educ. 2016, 239-245. [CrossRef]

53. Antohi, V.-M.; Zlati, M.L.; Ionescu, R.V.; Neculita, M.; Rusu, R.; Constantin, A. Attracting European Funds in the Romanian Economy and Leverage Points for Securing Their Sustainable Management: A Critical Auditing Analysis. Sustainability 2020, $12,5458$. [CrossRef]

54. Păunescu, C.; Molnar, E. Country's Entrepreneurial Environment Predictors for Starting a New Venture-Evidence for Romania. Sustainability 2020, 12, 7794. [CrossRef] 
55. Costache, C.; Dumitrascu, D.-D.; Maniu, I. Facilitators of and Barriers to Sustainable Development in Small and Medium-Sized Enterprises: A Descriptive Exploratory Study in Romania. Sustainability 2021, 13, 3213. [CrossRef]

56. Manning, L.; Smith, R.; Conley, G.; Halsey, L. Ecopreneurial Education and Support: Developing the Innovators of Today and Tomorrow. Sustainability 2020, 12, 9228. [CrossRef]

57. Hagebakken, G.; Reimers, C.; Solstad, E. Entrepreneurship Education as a Strategy to Build Regional Sustainability. Sustainability 2021, 13, 2529. [CrossRef]

58. Foss, N.J.; Klein, P.G.; Bylund, P.L. Entrepreneurship and the Economics of the Firm; SMG Working Paper No. 6/2011; Institut for Strategic Management and Globalization: Frederiksberg, Denmark. Available online: https://research-api.cbs.dk/ws/ portalfiles/portal/58916605/SMG_WP_6_2011.pdf (accessed on 21 March 2021).

59. Vodă, A.; Haller, A.-P.; Anichiti, A.; Butnaru, G. Testing Entrepreneurial Intention Determinants in Post-Transition Economies. Sustainability 2020, 12, 10370. [CrossRef]

60. Ajzen, I.; Fishbein, M. Understanding Attitudes and Predicting Social Behavior; Prentice Hall: Englewood Cliffs, NJ, USA, 1980.

61. Martin, C. Needs and Perspectives of Entrepreneurship Education for Postgraduate Students. A Romanian Case Study. J. Plus Educ. (JPE) 2015, 3, 153-157.

62. Leovaridis, C.; Frunzaru, V.; Cismaru, D. Entrepreneurial education in romanian universities. In Proceedings of the 10th International Technology, Education and Development Conference, IATED Academy, Valencia, Spain, 7-9 March 2016; 2016; Volume 1, pp. 92-102.

63. Dan, M.C.; Popescu, A.I. Entrepreneurship Education in Romanian Universities: Developing Student Entrepreneurial Behaviour. In Proceedings of the 10th International Conference on Education and New Learning Technologies, Palma, Spain, 2-4 July 2018; pp. 10130-10138, ISBN 978-84-09-02709-5.

64. Furdui, A. Analysis of the Entrepreneurial Ecosystem from Romania, Annals of the University of Petroșani. 2019. Available online: https: / / www.upet.ro/annals/economics/pdf/2019/p1/Furdui.pdf (accessed on 21 January 2021).

65. Furdui, A.; Edelhauser, E.; Popa, E.I. Innovation Management Correlated with the Models of Development of Technological Entrepreneurship. Qual. Access Success 2019, 20, 513-518, ISMB 1582-2559.

66. Edelhauser, E.; Ionica, A.; Leba, M. Modern Management Using IT \& C Technologies in Romanian Organizations. In Transformations in Business E Economics; Vilnius University: Vilnius, Lithuania, 2014; Volume 13, pp. 742-759. ISSN 1648-4460. Available online: http:/ / www.transformations.khf.vu.lt/32b/article/moder (accessed on 19 January 2021).

67. Anser, M.K.; Khan, M.A.; Awan, U.; Batool, R.; Zaman, K.; Imran, M.; Sasmoko, S.; Indrianti, Y.; Khan, A.; Abu Bakar, Z. The Role of Technological Innovation in a Dynamic Model of the Environmental Supply Chain Curve: Evidence from a Panel of 102 Countries. Processes 2020, 8, 1033. [CrossRef]

68. Law on National Education No. 1/2011. Available online: http://legislatie.just.ro/Public/DetailsDocument/125150 (accessed on 17 January 2021).

69. Recommendation of the European Parliament and of the Council of 18 December 2006 on key competences for lifelong learning Available online: https:/ / eur-lex.europa.eu/legal-content/RO/ALL/?uri=CELEX\%3A32006H0962 (accessed on 18 January 2021).

70. Yasir, N.; Mahmood, N.; Mehmood, H.; Babar, M.; Irfan, M.; Liren, A. Impact of Environmental, Social Values and the Consideration of Future Consequences for the Development of a Sustainable Entrepreneurial Intention. Sustainability 2021, $13,2648$. [CrossRef]

71. Densitate IMM Start-Up Nation 2020. Available online: https:/ / activ-advisor.ro/wp-content/uploads/2020/05/Densitate-IMMStart-up-Nation-2020.pdf (accessed on 20 March 2021).

72. Start-Up Nation 2018, Lista Rezultatelor Verificarilor in Cadrul Celei de-a Doua Editii a Schemei de Minimis. Available online: http:/ / www.imm.gov.ro/ro/2019/06/03/start-up-nation-2018-lista-rezultatelor-verificarilor-in-cadrul-celei-de-a-douaeditii-a-schemei-de-minimis / (accessed on 20 March 2021).

73. Romania Start-Up Plus si diaspora Start-Up Afla cate Afaceri Noi au fost Infiintate si in ce Domenii. Available online: https: / / www.fonduri-structurale.ro/stiri/22420/romania-start-up-plus-si-diaspora-start-up-afla-cate-afaceri-noi-au-fostinfiintate-si-in-ce-domenii (accessed on 20 March 2021).

74. Analiza CNIPMMR, Profilul Antreprenorului Beneficiar al Programului Start-Up Nation 2017. Available online: https: / / www.ceccarbusinessmagazine.ro/analiza-cnipmmr-profilul-antreprenorului-benefi-ciar-al-programului-start-up-nation-20 17-varsta-intre-31-45-ani-studii-universitare-in-special-in-domeniul-economic-a4852/ (accessed on 20 March 2021).

75. Zikmund, W.G. Sampling Designs and Sampling Procedures; Business Research Methods: South Western, OH, USA, 2005.

76. Education System in Romania, School Year 2018-2019, Synthetic Data. Available online: https://insse.ro/cms/sites / default/ files / field/publicatii / sistemuleducationalinromania_2018_2019_0.pdf (accessed on 17 December 2020).

77. National Institute of Statistics-Press Release 156 of June 25. 2019. Available online: https://insse.ro/cms/sites/default/files / com_presa/com_pdf/sistemul_educational_2019_r.pdf (accessed on 17 December 2020).

78. Sekaran, U. Research Methods for Business; Wiley and Sons: New York, NY, USA, 2008.

79. Remeikiene, R.; Startien, G.; Dumciuviene, D. Explaining Entrepreneurial Intention of University Students: The Role of Entrepreneurial Education. In Proceedings of the Management, Knowledge and Learning International Conference 2013, ToKnowPress, Zadar, Croatia, 19-21 June 2013.

80. Declaration from Osnabrück. Available online: https:/ / epale.ec.europa.eu/ro/content/partile-interesate-din-ue-sunt-de-acordasupra-educatiei-profesionale-ca-o-cale-de-urmat (accessed on 18 January 2021). 
81. Dézsi-Benyovszk, A.; Nagy, Á.; Szabó, T.P. Entrepreneurship in Romania Country Report 2014. Available online: https: //www.gemconsortium.org/report/49404 (accessed on 5 April 2021). 